\title{
Massive cryptic microbe-sponge deposits in a Devonian fore-reef slope (Elbingerode Reef Complex, Harz Mts., Germany)
}

\author{
Eberhard Gischler ${ }^{1} \cdot$ Arnold Fuchs $^{2} \cdot$ Wolfgang Bach $^{3} \cdot$ Joachim Reitner $^{4}$
}

Received: 27 April 2021 / Accepted: 7 August 2021 / Published online: 22 September 2021

(c) The Author(s) 2021

\begin{abstract}
A massive occurrence of microbial carbonates, including abundant sponge remains, within the Devonian Elbingerode Reef Complex was likely deposited in a former cavity of the fore-reef slope during the early Frasnian. It is suggested that the formation of microbial carbonate was to a large part favored by the activity of heterotrophic, i.e., sulfate-reducing bacteria, in analogy to Quaternary coral reef microbialites. The Elbingerode Reef Complex is an example of an oceanic or Darwinian barrier reef system. In modern barrier reef settings, microbialite formation is commonly further facilitated by weathering products from the central volcanic islands. The Devonian microbialites of the Elbingerode Reef Complex occur in the form of reticulate and laminated frameworks. Reticulate framework is rich in hexactinellid glass sponges, the tissue decay of which led to the formation of abundant micrite as well as peloidal and stromatactis textures. Supposed calcimicrobes such as Angusticellularia (formerly Angulocellularia) and Frutexites, also known from cryptic habitats, were part of the microbial association. The microbial degradation of sponge tissue likely also contributed to the laminated framework accretion as evidenced by the occurrence of remains of so-called "keratose" demosponges. Further typical textures in the microbialite of the Elbingerode Reef Complex include zebra limestone, i.e., the more or less regular intercalation of microbial carbonate and cement. Elevated concentrations of magnesium in the microbialite as compared to the surrounding metazoan (stromatoporoid-coral) reef limestone suggests that the microbialite of the Elbingerode Reef Complex was initially rich in high-magnesium calcite, which would be yet another parallel to modern, cryptic coral reef microbial carbonates. Deposition and accretion of the microbialite largely occurred in oxygenated seawater with suboxic episodes as indicated by the trace element $(\mathrm{REE}+\mathrm{Y})$ data.
\end{abstract}

Keywords Devonian $\cdot$ Reef $\cdot$ Microbialite $\cdot$ Carbonate $\cdot$ Sponge

\section{Introduction}

Biotic carbonate formation in carbonate factories is either biologically controlled as in tropical and cool water reefs or biologically induced as in mud-mounds and microbialites

Handling Editor: Jörn Peckmann.

Eberhard Gischler

gischler@em.uni-frankfurt.de

1 Institut für Geowissenschaften, Goethe-Universität, Altenhöferallee 1, 60438 Frankfurt am Main, Germany

2 Fischerweg 64, 18273 Güstrow, Germany

3 Geowissenschaften, Universität Bremen, Klagenfurter Straße, 28359 Bremen, Germany

4 Göttinger Zentrum Geowissenschaften, Universität Göttingen, Goldschmidtstraße 3, 37077 Göttingen, Germany
(Schlager 2000; James and Wood 2010). Riding and Virgone (2020) have further discussed the fact that combinations of these themes ("hybrid carbonates") are widespread both in fossil and modern depositional systems. Microbialites forming reef mounds and within metazoan reef systems have been common during earth history (Riding 1991a; Webb 1996; Riding and Virgone 2020; and references therein). Recent studies have shown that microbialites may occur also in great abundance in cryptic habitats of modern, postglacial high-energy tropical coral reefs (Reitner 1993; Montaggioni and Camoin 1993). Especially in volcanic settings, microbialites make up considerable volumes (up to $80 \%$ ) of the reef mass (Heindel et al. 2010). Meanwhile, several studies have shown that the presence of heterotrophic, sulfate-reducing bacteria is crucial for the formation of microbial carbonate within coral reef cavities, i.e., in cryptic reefal habitats (Heindel et al. 2010, 2012; Gischler et al. 2017), rather than 
cyanobacteria that are common in the classical lagoonal and marginal marine microbialite settings of western Australia or the Bahamas (e.g., Riding et al. 1991; Suosaari et al. 2016). Interestingly, sulfate reducers appear to be important agents for the formation of reef cements as well (Pigott and Land 1986). Sponges are often associated with microbial deposits both in fossil (Paleozoic and Mesozoic) mound and ancient and modern metazoan reef systems, likely as old as the Proterozoic (Reitner 1993; Brunton and Dixon 1994; Lee and Riding 2018; Gischler et al. 2017; Turner 2021). Sponges in fossil examples include archaeocyathids, lithistids, hexactinellids, the problematic receptaculitids or parts of this group (Fisher and Nitecki 1982), and so-called "keratose" sponges lacking solid mineral skeletons (Luo and Reitner 2014, 2016; Turner 2021). In modern coral reefs, demosponges and coralline sponges predominate (Reitner 1993; Reitner et al. 1995).

A curious microbial deposit with typical mud-mound characteristics (sensu Pratt 1982, 1995), including common laminated fine-grained carbonate ("mud"), stromatactis textures, zebra limestone, and sponge remains, has been described from within the mid-late Devonian shallow-water stromatoporid-coral Elbingerode Reef Complex in the Harz Mountains (Weller 1989a, b, 1991, 1995). Because of the textural characteristics, the deposit was described as a mound that grew in an embayment of the reef slope, in open water below the wave base, i.e., $>50 \mathrm{~m}$ depth, presumably via the formation of micrite by the activity of cyanobacteria (Weller 1989a, b). The appearance of the microbial carbonates, the geometry of the outcrop, and comparisons with modern deposits suggests, however, that the occurrence represents cryptic microbialites deposited in a larger reef cavity of the fore-reef slope rather than an open-water mound. Heterotrophic bacteria rather than cyanobacteria possibly favored carbonate production. Also, sponges may have played a much more crucial role in carbonate formation as previously assumed. As the Elbingerode "mud-mound" in the Harz Mountains might be a key occurrence to better understand sponge-microbial associations in general and cryptic microbialite formation in coral reefs in particular, we revisited this unique outcrop.

\section{Setting}

The Elbingerode Reef Complex is some $15 \mathrm{~km}$ long and about $5 \mathrm{~km}$ wide. It is located in the Paleozoic folded mountain belt of the Harz Mountains, Germany, which are part of the Variscan orogen and dominated by the occurrence of folded Devonian-Carboniferous sedimentary rocks (Figs. 1, 2). They were deposited in the narrow, elongated, northeast-trending Rhenohercynian Basin between Laurussia and Gondwana, i.e., the terrane assemblages of Avalonia and Armorica (Tait et al. 1997; Nance et al. 2010). In the basin, numerous coral-stromatoporoid reefs developed both on shelf and locally on volcanic settings in the basin (Krebs 1974). The Elbingerode Reef Complex and the adjacent Iberg Reef (Gischler 1995) are examples of the latter. Weller (2003) defined six stratigraphic units of the Elbingerode Reef Complex, including the late middle Devonian (Givetian) to early late Devonian (Frasnian) reef deposits, which reach a thickness of up to $600 \mathrm{~m}$. The stromatolitecoral reefs developed in the tropical realm at about $20^{\circ}$ southern latitude (Kiessling et al. 1999; Copper 2002). Carbonate production started in the Eifelian (Aehnelt and Weller 2004) likely on deeper, volcanic shoals with pelagic
Fig. 1 Location of the Elbingerode Reef Complex in the Variscan Harz Mts. of Germany including simplified paleogeography. Paleozoic outcrops of Harz Mts. and Rheinisches Schiefergebirge are outlined and marked by darker blue colors (modified from Gischler et al. 2004; based on Krebs 1974)

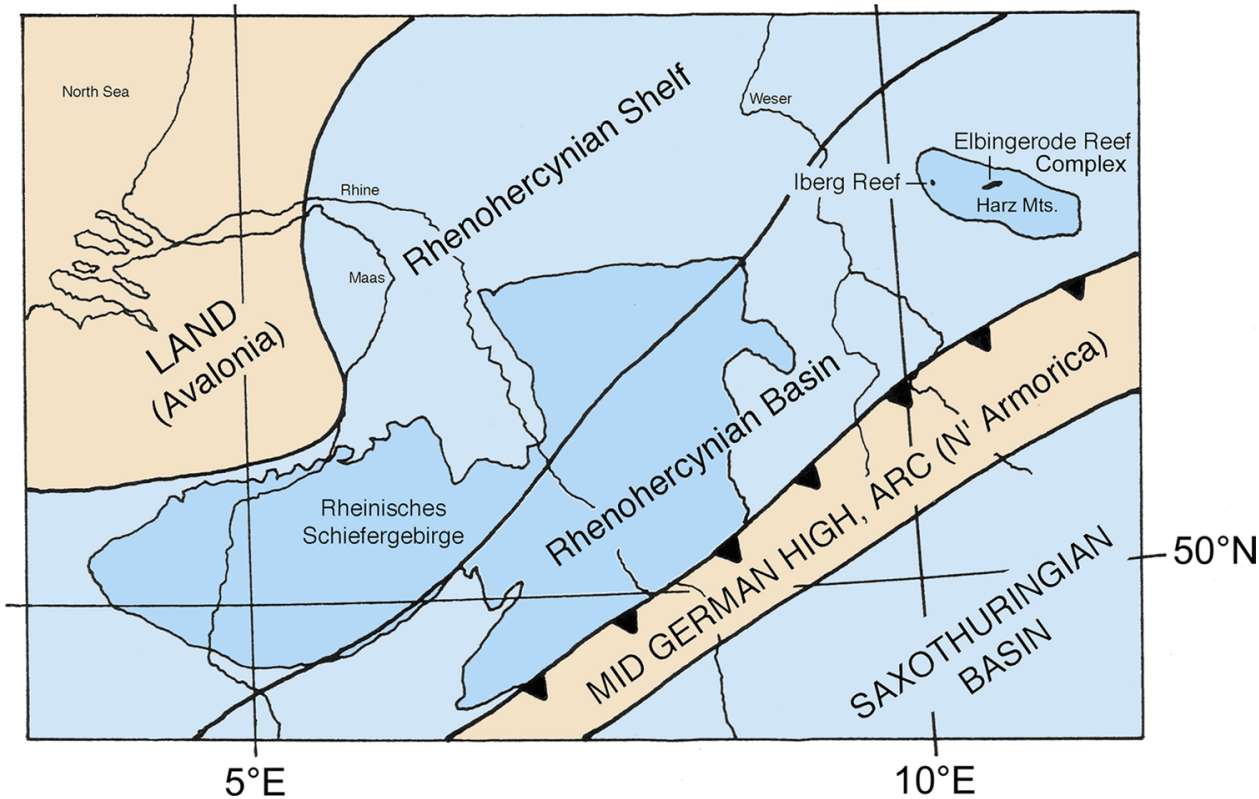




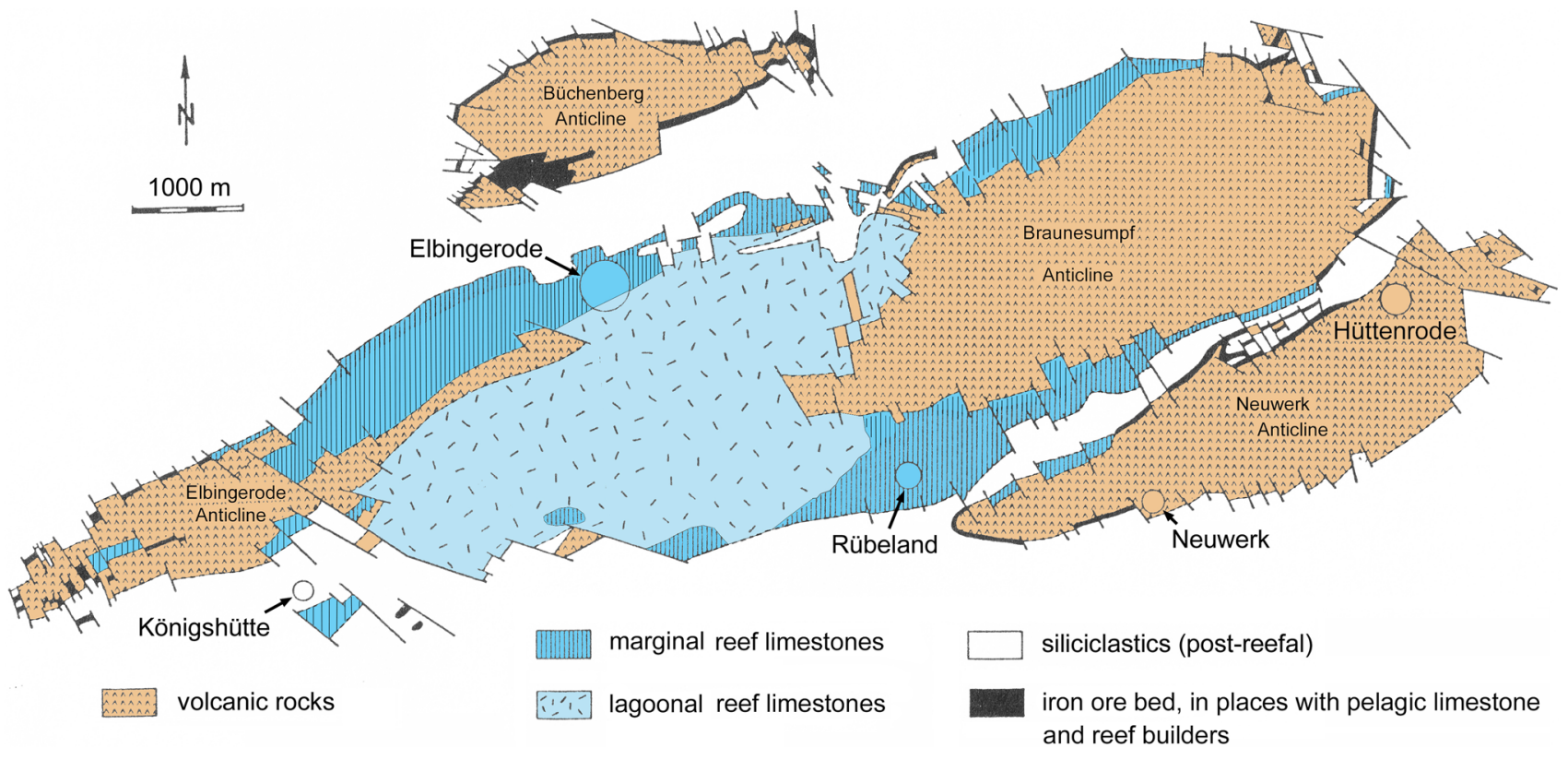

Fig. 2 Map of the Elbingerode Reef Complex including marginal and lagoonal reef limestone. The studied area of microbialites in Rübeland is indicated by arrow (modified after Fuchs 1990; Weller and Mucke 2014)

limestone and isolated, small reef structures. Shallow water reef growth began in the Givetian, lasted until the Frasnian, and was characterized by a well-developed oceanic barrier reef system (Fuchs 1990; Weller 1991). These authors have characterized the main phase of reef building as atoll-like based on the co-occurrence of marginal and lagoonal reef limestones (Fig. 2). However, as volcanic islands were present according to these authors, a typical barrier-reef geomorphology existed, similar to modern oceanic barrier-reef and almost-atoll systems that harbor several volcanic islands in the lagoon and are surrounded by one circular marginal reef. Comparable modern examples include, e.g., Raiatea and Tahaa, Society Islands (French Polynesia), the Gambier Islands (French Polynesia), Aitutaki (Cook Islands), and Chuuk (Caroline Islands) in the Pacific. The extensive occurrence of microbial deposits detailed here occurs within Frasnian fore-reef limestones. Based on conodont biostratigraphy, both the microbialite deposits and the directly surrounding reef limestones belong to the early Frasnian former Ancyrognathus triangularis zone (Fuchs 1986, 1987, 1989), i.e., the late Palmatolepis hassi to P. jamiae zones. The fact that in the early late Devonian marginal reef limestones of the Elbingerode Reef Complex eventually overlie lagoonal deposits and exhibit onlap, i.e., retrogradation, could be a consequence of a phase of increased relative sea-level rise (Fuchs 1990). There are no stromatoporoid-coral reefs following the Frasnian-Famennian boundary and isolated, deeper-water limestone deposits with brachiopods and deepwater corals as well as conodont ghost faunas of the Famennian and early Carboniferous are evidence of a subsequent seamount phase of the Elbingerode Reef Complex (Fuchs 1987; Weller 1991, 2003; Gischler et al. 2004). Because global sea level peaked in the early Frasnian and fell in the late Frasnian and Famennian (Haq and Schutter 2008), subsidence rather than sea-level change was presumably a major driver of the late development of the Elbingerode Reef Complex. Sedimentation in and around the reef complex ended with deep-water (shale, greywacke) and olisthostrome deposits of the Famennian and early Carboniferous, respectively (Weller 2003, 2008).

\section{Materials and methods}

This study builds on a previous $\mathrm{PhD}$ thesis (Fuchs 1986) and a previous Diploma thesis (Ahlbrecht 1997) performed in the Elbingerode Reef Complex in general and the Rübeland area in particular in which the authors were involved. Subsequently, we have collected a total of some 50 large hand specimens in the microbial deposit, mainly at the southern slope of the Bode river valley opposite the train station and subordinately at the northern slope in the village of Rübeland (Figs. 3, 4; Table 1). Two short (ca. $2 \mathrm{~m}$ long), horizontally drilled cores from within the old Cave Restaurant building were provided by the owner. Sample stations were located using maps and profiles of Fuchs (1986) and Weller (1991), the topographic map no. 4231-NW Rübeland, scale 1:10,000, and a Garmin 2000 GPS. All specimens were cut and polished to obtain large (several $100 \mathrm{~cm}^{2}$ ) sections for facies interpretation. Twenty-three large thin-sections 
Fig. 3 Map of Rübeland showing the study area south of the River Bode, opposite of the railway station. The study area, i.e., steep slope southeast of the street (Burgstrasse and Hasselfelder Strasse) is shown on Figs. 4 and 5. Samples not shown on Fig. 4 (on northern slope of Bode valley) are indicated. From topographic map no. 4231-NW Rübeland, scale $1: 10,000$

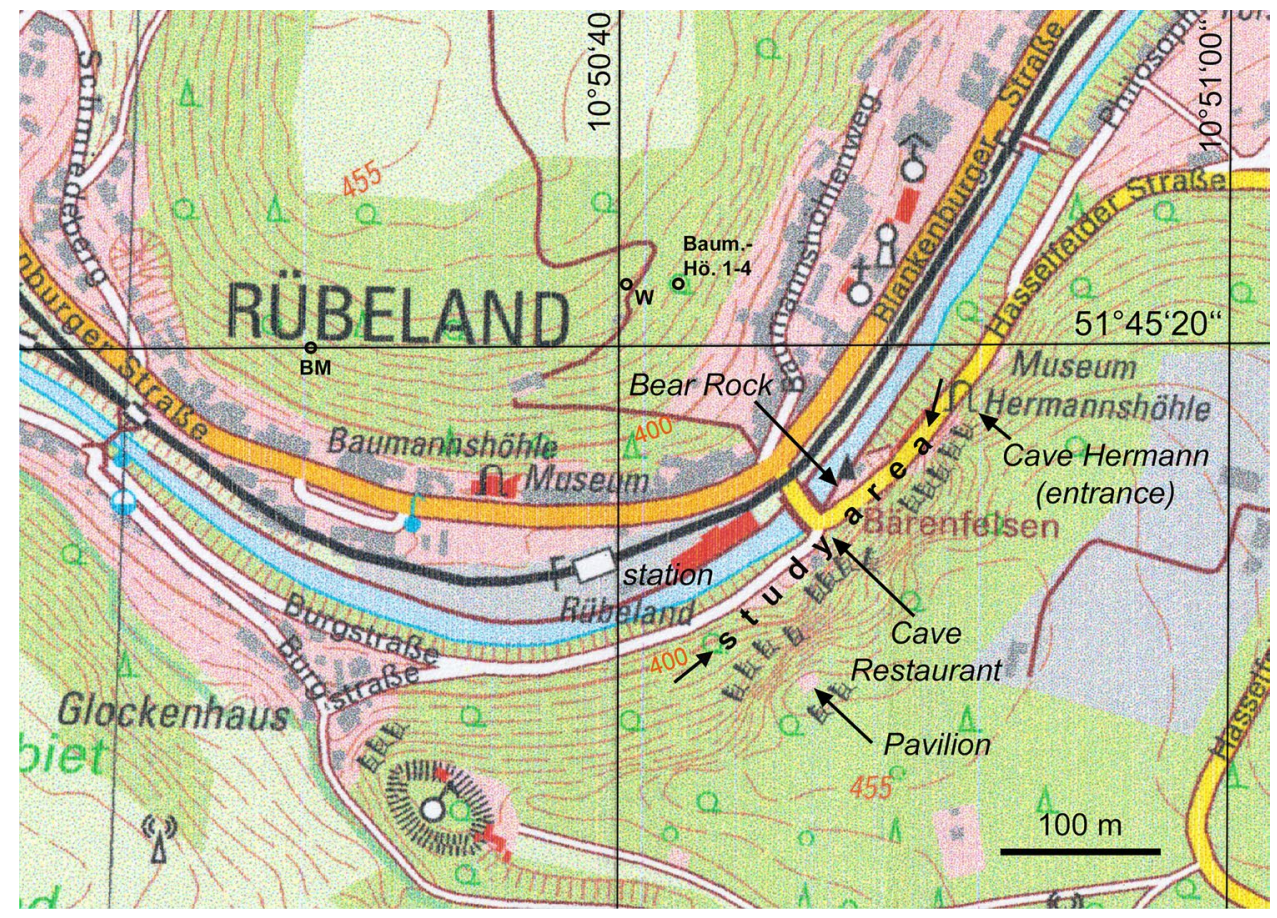

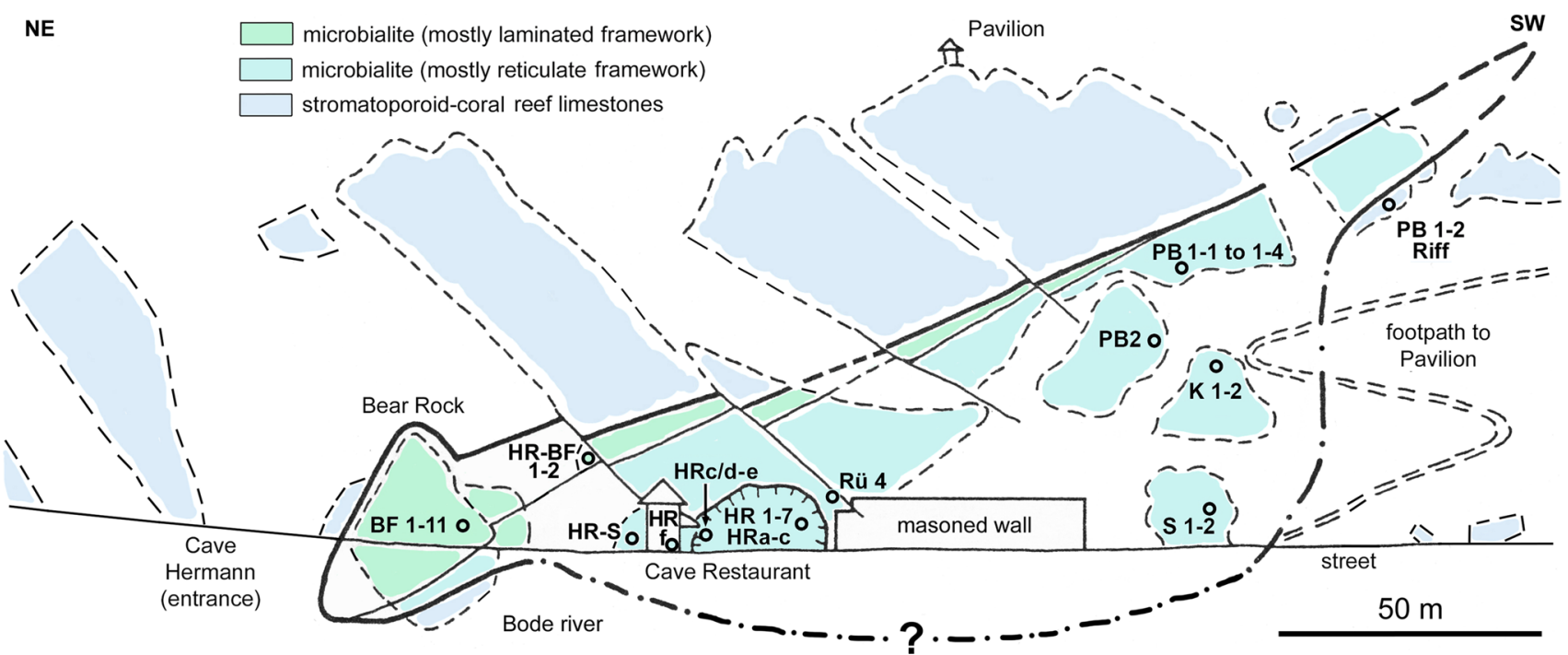

Fig. 4 Newly collected samples on the southeastern slope of the Bode valley opposite the railway station in Rübeland including distribution of facies (view of slope modified after Fuchs 1986; Weller 1991). See also Fig. 3 for locations of landmarks

$(9 \times 6 \mathrm{~cm})$ were made and investigated on a LEICA polarization microscope.

Twenty-five conodont samples of the work of Fuchs (1986, 1987, 1989) and 15 new conodont samples were revisited and analyzed, respectively, to validate the previous age determinations for the microbial deposits and the surrounding reef limestones (Fig. 5). One kilogram of crushed limestone was dissolved in $10 \mathrm{~L}$ of $1-\mathrm{N}$ formic acid. The non-carbonate residue was washed through a $63 \mu \mathrm{m}$-sieve, dried, and then inspected under a binocular microscope.

Nine pulverized subsamples were drilled from polished slabs for the analysis of mineral phases using X-ray diffraction (Panalytical Xpert Pro) following the method of Milliman (1974), and 44 samples drilled for the analysis of stable oxygen and carbon isotopes $\left(\delta^{18} \mathrm{O}, \delta^{13} \mathrm{C}\right)$ on a ThermoFinnigan MAT 253 mass spectrometer with gas bench II following the method of Spötl and Vennemann (2003). 


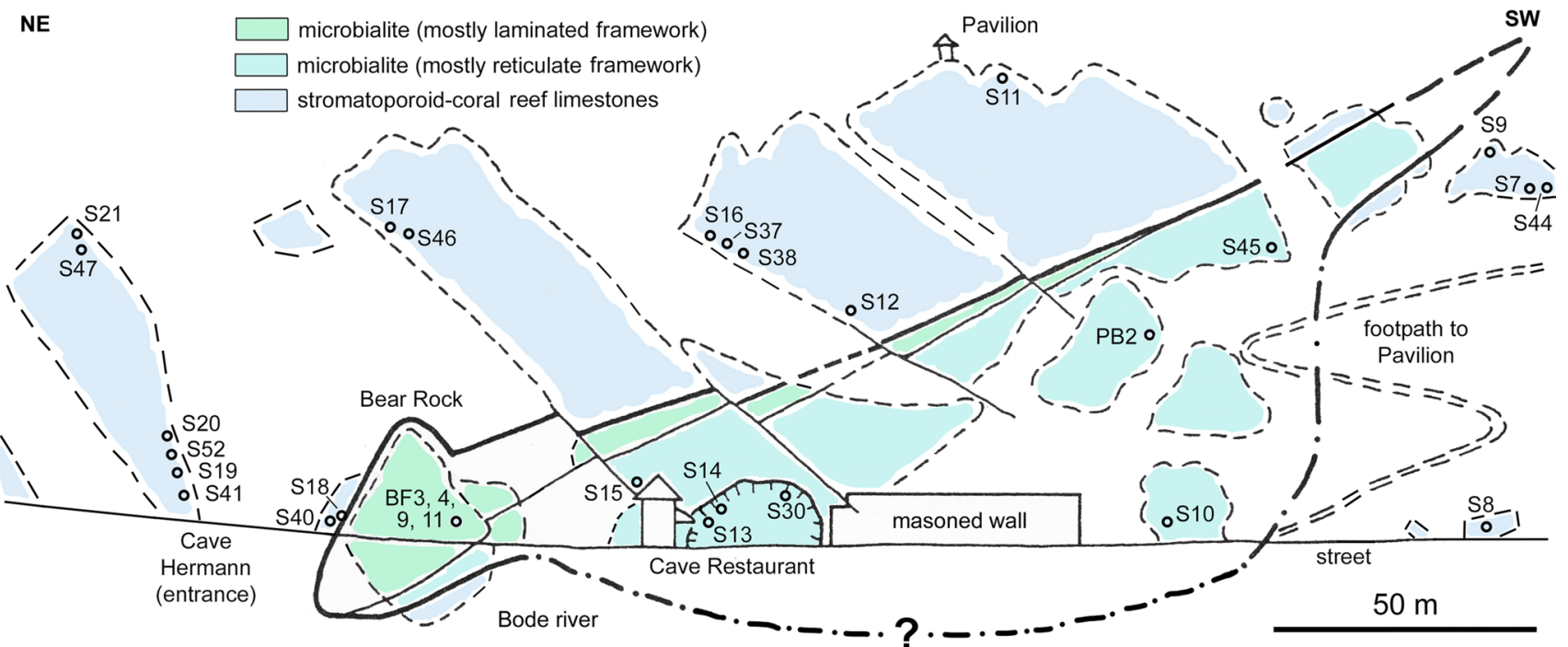

Fig. 5 Conodont samples from the investigated area in Rübeland (view of slope modified after Fuchs 1986; Weller 1991). See also Fig. 3 for locations of landmarks

Trace element concentrations of calcite from a polished sample (Rü 4) from near the Cave Restaurant locality were determined by laser-ablation inductively coupled plasma mass spectrometry (LAICPMS) at the University of Bremen using the procedure outlined in Jonkers et al. (2021). An in-house glass standard was measured on a daily basis to monitor and correct for the production of the doubly ionized ${ }^{86} \mathrm{Sr}^{++}$and its isobaric interference on ${ }^{43} \mathrm{Ca}^{+}$, which was used as internal Standard. Accuracy and precision were monitored by measuring references materials $\mathrm{BCR} 2 \mathrm{G}, \mathrm{BHVO} 2 \mathrm{G}$, and MACS-3 and were generally $<10-15 \%$ for the rare-earth elements.

\section{Results}

\section{Field observations}

The microbial limestone body is exposed on the southeastern slope of the Bode valley opposite of the railway station in the town of Rübeland. There are several large, isolated cliffs separated by a steep slope that is mostly densely wooded. The cliffs are hard to access. Prominent outcrops accessible from the road at the base include the artificial excavation of the "Höhlenrestaurant" (Cave Restaurant) and the "Bärenfelsen" (Bear Rock), the latter a remnant of a road cut into the reef limestone. According to our observations and the slope profiles of Fuchs (1986), Weller (1991), and Ahlbrecht (1997), the microbialite limestones are some $250 \mathrm{~m}$ in diameter and up to $60 \mathrm{~m}$ thick (Fig. 4). They might be thicker, but the base of the occurrence is only partly exposed below
Bear Rock. In the vicinity of the Cave Restaurant, the limestone exhibits clearly visible layering, which dips approximately $30^{\circ}$ towards the northeast. The microbialite body is surrounded and overlain at the top by coral-stromatoporoid reef limestone. Weller (1991: fig. 10) mapped the microbialite as extending several hundred meters to the west along the northern bank of the Bode river and to the north on the northern slope of the Bode valley. Based on our mapping, the microbialite body does not extend that far and is mainly located south of the railway station. Unfortunately, the outcrop conditions on the northern bank of the river and the valley slope are mediocre at best. Microbial limestones at the northern slope of the river valley mostly appear to be locally restricted fillings of neptunian dikes, which are commonly younger than the main microbialite body and reach into the early Famennian. The appearance of the Elbingerode Reef Complex was influenced by tectonics (Ruchholz 1989). The original shape of the microbial limestone body is not preserved due to tectonic faulting, according to Weller (1991). Folding might have played a role as well (Friedel and Janssen 1988), as seen in the $30^{\circ}$ dip toward the northeast, whereas the original fore-reef slope would be outward, to the southeast. Still, the mapping does not reveal a mound-shaped but a trough-shaped ("anti-mound") occurrence. Presumably, compaction can be largely excluded due to rapid early marine cementation in the surrounding fore-reef limestones (Krebs 1969; Janssen et al. 1990; Grammer et al. 1993). For comparison, Mossop (1972) has shown that compaction in the Devonian Redwater Reef, Canada, was significantly lower in marginal (fore-reef and reef limestones) as opposed to lagoonal reef limestone. 


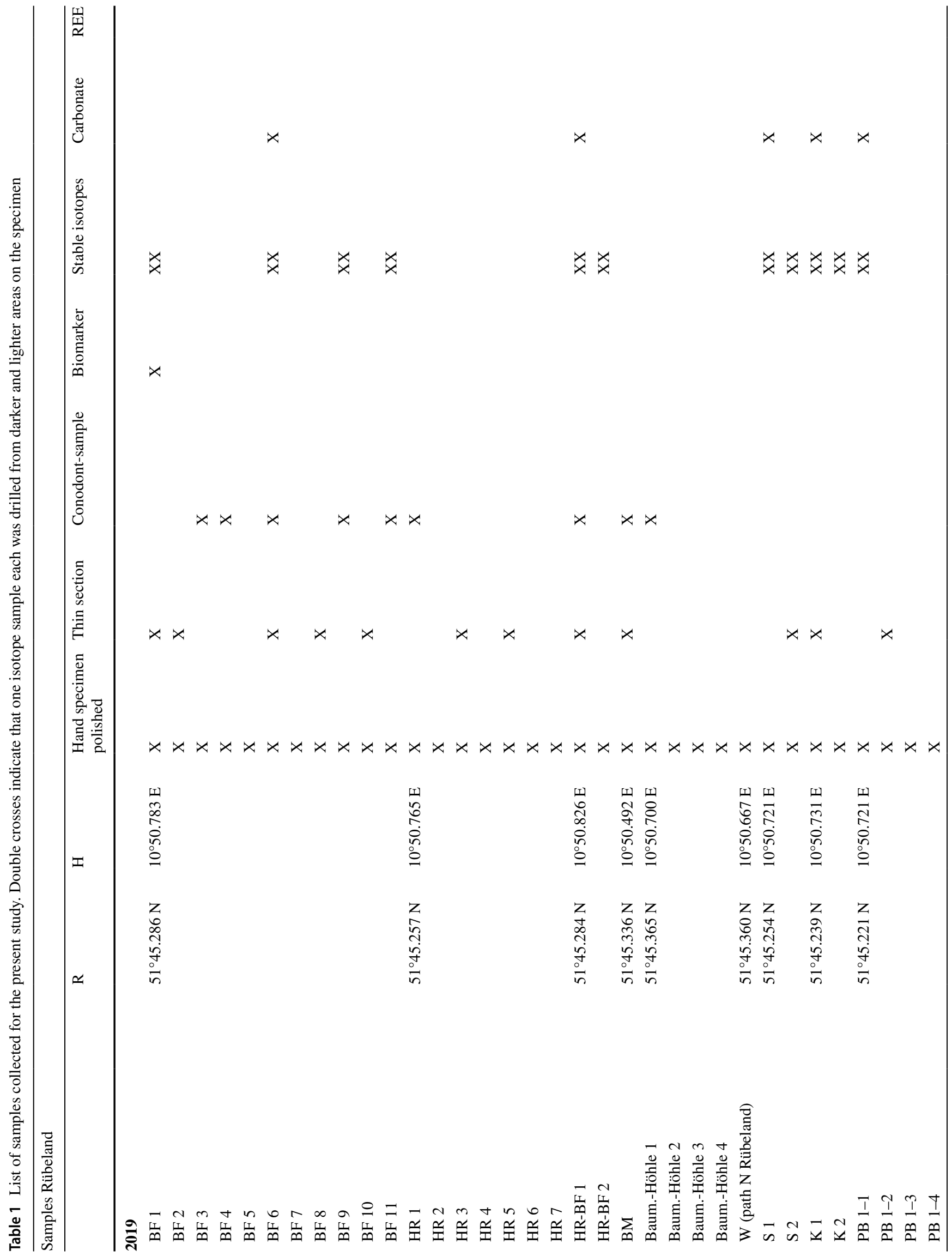




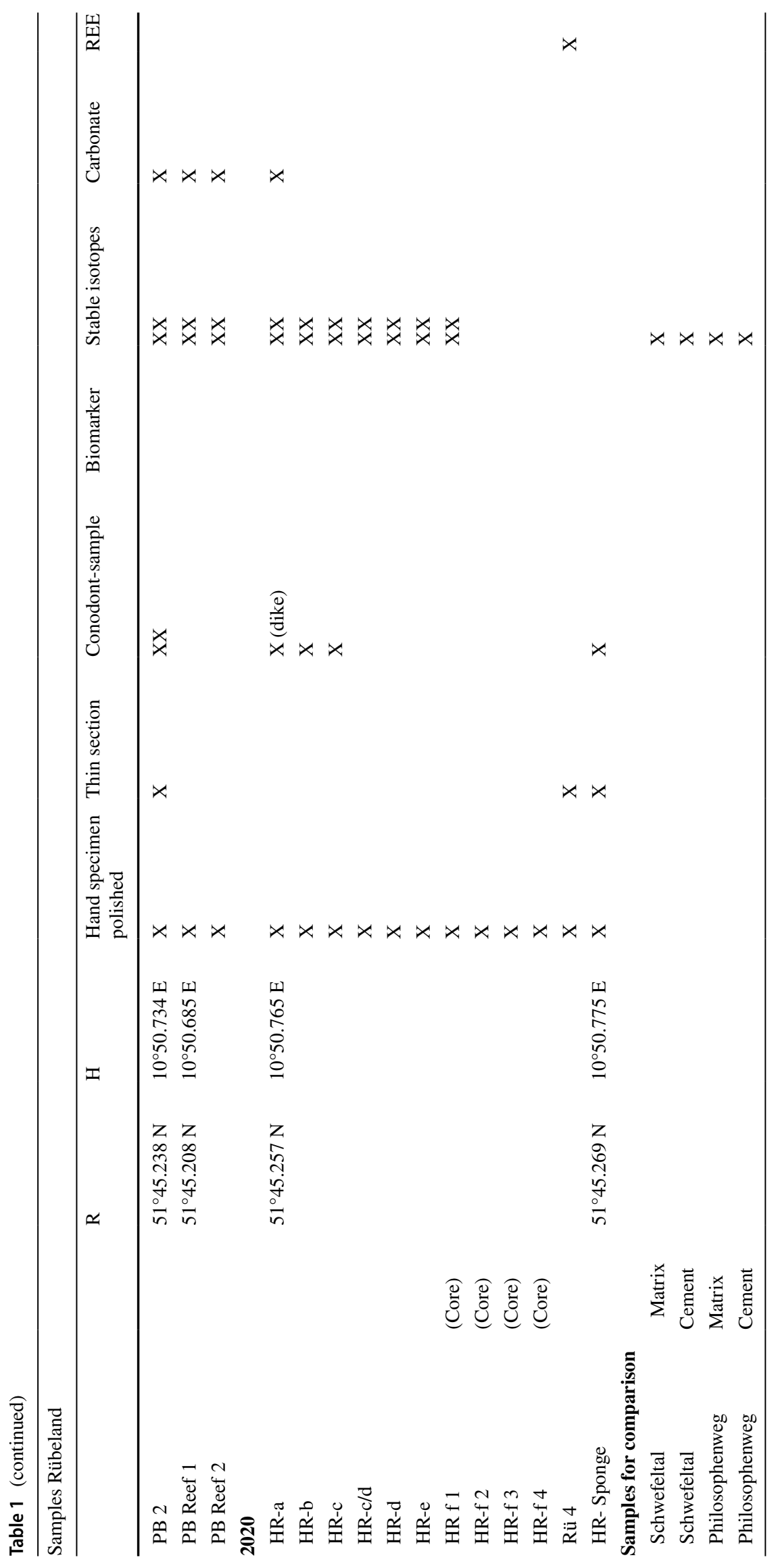




\section{Biostratigraphy}

Both the microbial limestones and the surrounding fore-reef limestones contain conodonts. They are usually black, i.e., preserved with a color alteration index of 4-5 (Fuchs 1987). Conodont biostratigraphy of samples from the southeastern slope of the Bode River in Rübeland has revealed an early Frasnian age, i.e., the former Ancyrognathus triangularis conodont zone (Fuchs 1986, 1987, 1989) for both the microbialite and the surrounding stromatoporoid-coral reef limestones. According to the revised, standard conodont zonation of Ziegler and Sandberg (1990), this corresponds to the late Palmatolepis hassi to Palmatolepis jamiae zones. Age-indicative conodonts identified include Palmatolepis subrecta, Palmatolepis proversa, Palmatolepis punctata, Ancyrognathus triangularis, Ancyrognathus nodosa, Ancyrognathus gigas, Polygnathus decorosus, Polygnathus alatus, Polygnathus webbi, and Icriodus symmetricus (Fig. 5; Table 2). Conodonts are more abundant in the reticulate as compared to the laminated framework (see below). For the first time, conodonts were recovered also from the youngest part of the microbialite, i.e., the Bear Rock locality. They also indicate late Palmatolepis hassi to Palmatolepis jamiae zones. Further to the northeast, reef limestone belongs to the former Polygnathus asymmetricus zone, now Palmatolepis falsiovalis to early Palmatolepis hassi zones. Microbial fillings of neptunian dikes had either similar, i.e., early Frasnian ages as well as late Frasnian and early Famennian ages (Table 2).

\section{Macrofacies}

The main body of the microbialite is characterized by finegrained or microcrystalline carbonate in gray, dark gray, and white colors and fenestral stromatactis textures (Figs. 6, 7). There are only mud-supported, no grain-supported textures visible, i.e., largely mudstone and wackestone as well as microbial boundstone. In some cases, especially in the lower and middle part of the microbialite body, layering is visible only on hand specimens, and rather irregular exhibiting partly thrombolitic or reticulate patterns as described by Pratt (1982). The size of stromatactis varies within a few centimeters in diameter (Fig. 6a-d). Some former cavities are filled by two generations of up to $1-2 \mathrm{~cm}$ thick cement crusts (Fig. 6c, d). The first generation fringing the rims of cavities shows lengthy crystals of radiaxial fibrous calcite and the remaining of the voids are filled with blocky calcite spar. Stromatactis show a large variety of shapes and classical examples with horizontal bases and irregular ("flame-like") tops are moderately common only (Fig. 6a-d). Macrofauna was encountered scarcely and includes crinoid ossicles and unidentified shell remains, possibly derived from brachiopods or mollusks. One largely intact ammonoid shell was found (sample PB 2) (Fig. 7f). In the Cave
Restaurant outcrop, where a layering or bedding and stromatactis textures are well-visible due to the weathered rock surfaces, cross sections through large sponge body fossils with diameters of up to $8 \mathrm{~cm}$ are common (Fig. 7b-d). They were identified previously as early hexactinose glass sponges (Mehl 1996). This identification was confirmed during this study. A few of the sponge body fossils exhibit well-developed geopetals with one or two generations of fine-grained carbonate at the base and two generations of large cement crystals in former hollows of the top (Fig. 7b). The geopetals dip towards the northeast, like the bedding, suggesting post-depositional rotation of the microbial deposit by some $30^{\circ}$ from the horizontal. In one case, two generations of fine-grained carbonate in one geopetal exhibit slightly different dip angles, which would point to syndepositional redeposition. So-called zebra limestone, i.e., more or less regularly alternating layers of fine-grained carbonate and cement, was found in abundance at the level of the Cave Restaurant (Fig. 7a).

Above the Cave Restaurant, samples HR-BF and samples $\mathrm{BF}$ from the Bear Rock represent the uppermost parts of the microbial deposit. These limestones exhibit regular lamination and bedding of dark gray and white, sometimes reddish mudstone (Fig. 8b-d). At the Bear Rock proper, bedding is often chaotic and suggests slumping and sliding (Fig. 8c). At a few places, domal structures of up to $30 \mathrm{~cm}$ diameter are found (Fig. 8a), which Weller (1989a, b) named Ursoscopulus stromatolites based on the locality. The transition from the reticulate to the laminated framework was possibly recovered in sample PB 2 (see Figs. 4, 7f). Biostratigraphical data suggests deposition in the same conodont zone. Alternatively, the laminated facies in this sample could represent a slightly younger neptunian dike filling. Texturally similar limestones with laminated mudstone, mostly with red stain, occur in younger neptunian dikes, e.g., above the HR-BF samples (S 30, 37, 38, 40, 41; Fig. 5), and at the northern slope of the Bode valley at the entrances to Cave Baumann (Fig. 8e, f). The dike fillings belong to the late Frasnian and early Famennian.

\section{Microfacies}

Microcrystalline carbonate is abundant in the reticulate framework (Fig. 9a-d). Mudstone and wackestone textures predominate; grain-supported textures of packstone are very rare. In places, the fine carbonate contains fine biogenic detritus including mollusk, brachiopod, and ostracod shell fragments, crinoid ossicles, cross sections and longitudinal sections through tentaculites, and various sponge spicules (Fig. 9c, d). Stromatoporoid fragments from the surrounding reef framework are found rarely. Peloids, likely of fecal origin, are moderately common. Fenestral cavities are usually occupied by radiaxial-fibrous calcite cement 
Table 2 Composition of conodont samples from microbialites and adjacent rocks in Rübeland (including data from Fuchs 1986)

\section{falsiovalis to early hassi Zone}

(former Polygnathus asymmetricus Zone):

\section{S18}

Polygnathus pennatus

S19

Polygnathus pennatus

S20

Polygnathus dubius

S21

Polygnathus ovalis

Late hassi to jamiae Zone

(former Ancyrognathus triangularis Zone):

S7

Palmatolepis subrecta

Ancyrognathus triangularis

S8

Palmatolepis subrecta

Polygnathus decorosus

Icriodus symmetricus

S9

Palmatolepis subrecta

Ancyrodella nodosa

Polygnathus decorosus

S10

Palmatoplepis subrecta

Ancyrognathus triangularis

S11

Palmatolepis subrecta

Ancyrognathus triangularis

S12

Palmatolepis subrecta

\section{S13}

Palmatolepis subrecta

Ancyrognathus triangularis

Ancyrodella nodosa

S14

Palmatolepis subrecta

Ancyrognathus triangularis

S15

Palmatolepis subrecta

Ancyrodella nodosa

Polygnathus decorosus

Polygnathus alatus

S16

Palmatolepis subrecta

S17

Palmatolepis subrecta
Table 2 (continued)

BF 3

Barren

BF 4

Barren

BF 6

Palmatolepis subrecta (juvenile)

Hindeodella sp.

BF 9

Palmatolepis subrecta

Polygnathus dengleri

Hindeodella sp.

Ozarkodina sp.

BF 11

Ancyrognathus triangularis

Palmatolepis subrecta

Polygnathus dengleri

Icriodus symmetricus

HR 1

Palmatolepis subrecta

Polygnathus alatus

Ozarkodina sp.

\section{HR-BF 1}

Barren

\section{BM}

Ancyrognathus triangularis
Palmatolepis subrecta
Polygnathus dubius
Various Hindeodella sp. and Ozarkodina sp.
Problematica

\section{PB 2 not laminated}

Rich conodont fauna:

Ancyrognathus triangularis

Ancyrodella nodosa

Palmatolepis subrecta

Polygnathus webbi

Ozarkodina sp.

Hindeodella sp.

Conodont pearl

Bryozoa?

\section{PB 2 laminated}

Plenty of unsoluble residue; fewer conodonts:

Ancyrognathus triangularis

Ancyrodella nodosa

Palmatolepis subrecta

Polygnathus webbi

Polygnathus dubius

Ozarkodina sp. 
Table 2 (continued)

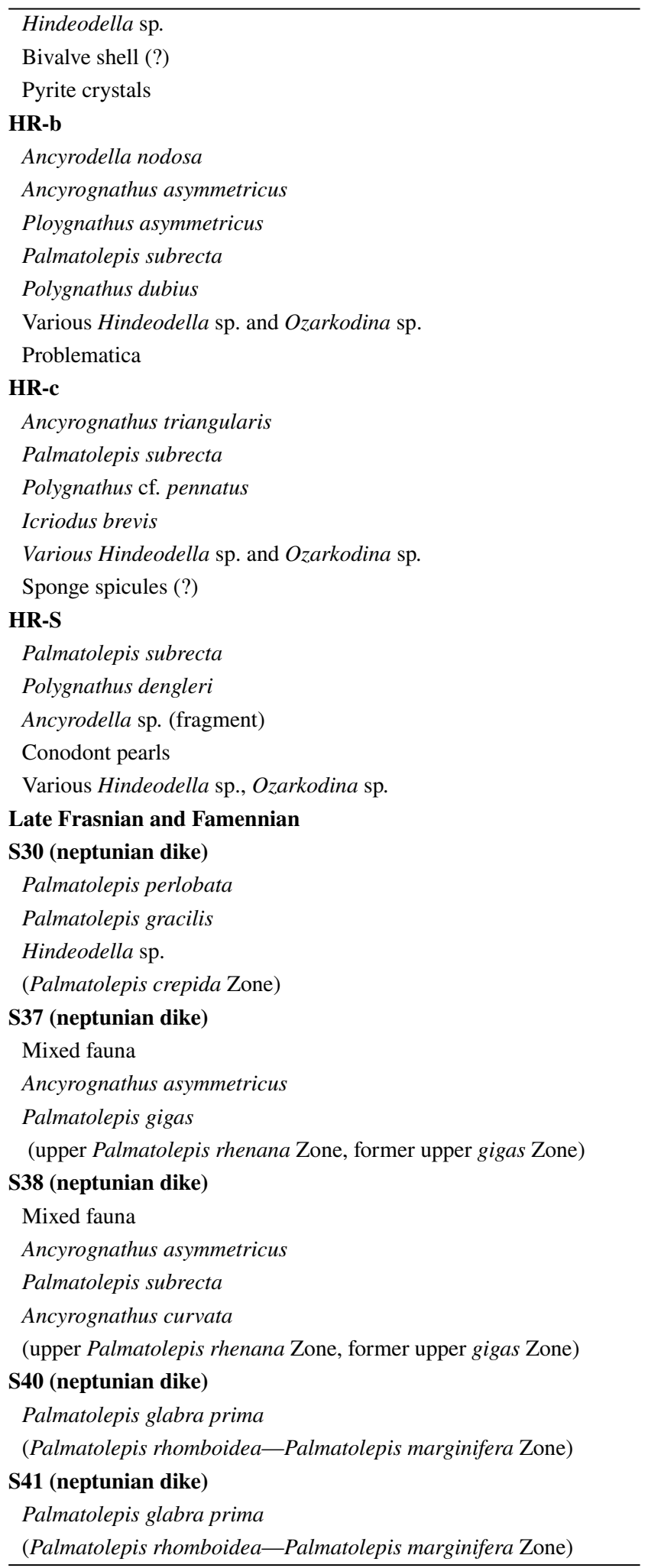

Table 2 (continued)

S44
Barren
S45
Barren
S46
Barren
S47
Barren
S52
Barren
HR-a (neptunian dike)
Palmatolepis gracilis
Palmatolepis crepida
Palmatolepis cf. glabra (fragment)
Various Hindeodella sp.
"Cornets"
Quartz crystals
(Palmatolepis crepida Zone)

and by blocky calcite spar. When both cement types occur, the former lines the rims and the latter fills in the remaining former pore space (Fig. 9a). The large sponge body fossils are very instructive, because they exhibit a number of different textures (Figs. 9e, f; 10a-e). The wall tissue is altered and may either show a peloidal "spongiform" texture (after Pratt 1982) (Fig. 9e, f), stromatactoid, fenestral textures (Fig. 10a-c), or there are remains of connected spicule framework belonging to hexactinose Hexactinellida (Fig. 10d, e). In the former spongocoel of the large sponge body fossils, one or two generations of fine-grained carbonate (mud) can be distinguished, with the second one being somewhat coarser than the first one. The top of the former cavity is lined with both radiaxial fibrous and dogtooth spar. Some crystals of the latter may reach several millimeters in length (Fig. 10f). In places, tiny bushes and irregular patches of fine-grained carbonate in the reticulate framework are reminiscent of calcified microbes of the Angusticellularia and Epiphyton types (Figs. 9b; 10a, b).

Zebra limestone is common at the level of the old Cave Restaurant building and characterized by $\mathrm{cm}$-thick alternating layers of fine-grained carbonate and radiaxial fibrous, and, less commonly, by blocky calcite cements (Fig. 10c). The fine-grained carbonate contains biogenic detritus, including thin shell fragments of mollusks, tentaculitids, ostracods, and crinoid fragments. Zebra limestone sections do not exceed a few tens of centimeters in thickness. 
In the laminated framework of the microbialite, exposed above the Cave Restaurant building and largely at the Bear Rock locality, very fine-grained carbonate is ubiquitous (Fig. 11). Mudstone textures predominate, whereas, wackestone is rare. Individual laminae are well-discernible in thin-section; either by slightly different colors, textures, or fossil content (Fig. 11a, c). Laminae may exhibit upward fining, which is visible in a change from somewhat lighter to darker color from bottom to top (Fig. 11e). In cases, several laminae (2-3) are visible in thin-section, which appear as one layer in the macroscopic view of the polished hand specimens. We were not able to see clear patterns regarding different textures or fossil content between the darker and the lighter laminae as suggested by Weller (1989a, b). Generally, biogenic detritus is much less common in the laminated as compared to the reticulate framework of the microbialite deposit. Even so, small and thin shells and shell fragments, e.g., from ostracods and tentaculitids, as well as sponge spicules occur in the laminated framework (Fig. 11e). In many cases, laminae appear to be completely composed of a delicate framework or network of anastomosing sponge spicules (Fig. 11d-f). They resemble the structures left by so-called "keratose" sponges as described and reviewed by Luo and Reitner (2014, 2016). Peloids are commonly concentrated at the contacts of the laminae (Fig. 11a). Another component of the mudstone and wackestone layers includes irregularly shaped, black dots that are presumably remains of altered organic matter or pyrite (Fig. 11e, f). At the Bear Rock location, where the smallest grain sizes occur, mudstone and wackestone exhibit small (up to $0.5 \mathrm{~mm}$ diameter) sections through roundish and ellipsoidally shaped former voids, which most likely represent burrows that are evidence of bioturbation of unknown origin (Fig. 11b). Occasional reddish, bushy patches are reminiscent of Frutexites (Fig. 12f). Laminated framework including the above-described characteristics is also seen commonly as fillings of neptunian dikes including upward fining, peloidal accumulations, and "keratose" sponge frameworks (Fig. 12).

\section{Geochemistry}

The microbial limestones consist entirely of low-magnesium calcite (Table 3). High-magnesium calcite and aragonite were not identified. Quartz is accessory with $1.5 \%$ abundance. Previous work has revealed that the total carbonate content of the microbial limestones ranges from $89 \%$ to $92 \%$ (Ahlbrecht 1997) and from $89 \%$ to $99 \%$ (average $94 \%$ ) (Oesterreich 1991), respectively. The carbonate content of the surrounding reef limestone is somewhat higher with $97.9 \%$ on average (Oesterreich 1991). Interestingly, magnesium contents in the microbialites amount to $3200 \mathrm{ppm}$ on average and are significantly higher as compared to the mean value of $1900 \mathrm{ppm}$ in the surrounding reef limestones
(Oesterreich 1991). Comparable results were obtained by Ahlbrecht (1997) who measured 1.13-1.29 mol\% $\mathrm{MgCO}_{3}$ in the microbial limestones as compared to $0.86 \mathrm{~mol} \%$ in the surrounding reef limestones on average. Stable isotopes of oxygen and carbon range from -8.90 to $-4.01 \%$ for $\delta^{18} \mathrm{O}$ (mean $-5.83 \%$ ) and from 1.09 to $2.91 \%$ for $\delta^{13} \mathrm{C}$ (mean $1.36 \% o$ ). No isotopic differences exist between microbialites and surrounding reef limestones (Fig. 13). Shale-normalized (PAAS = Post Archaen Average Shale) rare earth element and $\mathrm{Y}$ patterns in a sample that comprises both reticulate and laminated facies, show distinct negative $\mathrm{Ce}$ anomalies and positive $\mathrm{Y}$ anomalies (Fig. 14). Some domains of the sample analyzed exhibit minor enrichment of mid-REE. An enrichment of light REE is lacking. The concentration of mid-REE neodymium appears to be correlated with Fe contents (Fig. 15).

\section{Discussion}

The data individually and collectively suggests that a large majority of the fine carbonate of the Rübeland microbialite formed by the degradation of former sponge tissue in combination with the activity of heterotrophic and other bacteria, likely in a large cavity or cave of the fore-reef slope. Microfacies data show that sponge tissue was altered to abundant fine-grained carbonate, stromatactis, and peloidal ("spongiform") textures. Even though numerous and in part opposing models have been put forward to explain the genesis of stromatactis relying on both biotic and abiotic agents, several studies have convincingly confirmed also that the degradation of sponge tissue may produce the characteristic fenestral textures (Bourque and Gignac 1983; Bourque and Boulvain 1993; Aubrecht 2011, and references therein). The common occurrence of large sponge body fossils, mostly hexactinose hexactinellids, in various stages of disintegration, especially in and around the Cave Restaurant outcrops along with abundant stromatactis lends strong evidence to this assumption. The facies mostly exhibits an irregular, reticulate framework as described by Pratt (1982). This author explained the origin of reticulate texture by laterally discontinuous microbial mats accumulating calcium carbonate.

In analogy to modern reef cavities, it is speculated that heterotrophic bacteria such as sulfate reducers were mediating the precipitation of carbonate. Pigott and Land (1986) have shown that sulfate reduction of organic matter produces bicarbonate $\left(\mathrm{HCO}_{3}{ }^{-}\right)$and may thereby fuel calcium carbonate precipitation in reef cavities and reef framework. Heindel et al. (2010, 2012) concluded that sulfate-reducing bacteria favored cryptic microbialite formation in late Quaternary reefs via the degradation of organic matter in anoxic micro-environments. The attempt to possibly find evidence for the former existence of sulfate-reducing bacteria in the 


४Fig. 6 Polished hand specimens exhibiting reticulate microbial framework. a Irregularly layered sample PB 1-1 showing stromatactoid textures. b Largely layered sample PB 1-2. c Stromatactoid texture in sample PB 1-4. d Reticulate texture with thick fibrous cement crusts in former cavities; sample $\mathrm{S} 2$. Scale of grid in background is $1 \mathrm{~cm}$

microbialites of the Elbingerode Reef Complex by molecular fossil, i.e., lipid biomarkers was not successful, likely due to the high temperature and pressure influence during Variscan orogeny. The fact that the Elbingerode Reef Complex had a typical oceanic barrier reef geomorphology suggests that microbialite accretion was in addition boosted via fertilization by run-off from the central volcanic islands. This effect has been observed in late Quaternary barrier reef microbialite examples such as Tahiti, French Polynesia, and Espirito Santo, Vanuatu, where weathering of volcanic rocks provided nutrients, stimulated primary production, and boosted the development of very thick microbialite crusts that may constitute up to $80 \%$ volume of the reef framework (Heindel et al. 2010, 2012). Abundant reef microbialite has also been forming in Quaternary non-volcanic settings, however, not in such high volumes as compared to volcanic reef locations.

Remains of bushy, digitate calcimicrobes belonging to Angusticellularia, Epiphyton, and Frutexites have been reported also from the microbialites of the Elbingerode Reef Complex by Weller (1995) and Ahlbrecht (1997). Girvanella as potential producer of fine-grained carbonate (Pratt 2001) was neither observed during this nor in previous studies. The occurrence of Angustocellularia and Frutexites would fit the interpretation of a submarine cave deposit for the microbialite as both taxa have been reported previously from deep-water and cryptic deposits (Riding 1991b; Böhm and Brachert 1993; and references therein). However, the latter authors have discussed Frutexites as being either of organic or inorganic origin. The systematic affiliation of Epiphyton is uncertain and could be either microbial or algal (Riding 1991b). The inferred coccoid cyanobacteria of Weller (1995) measure up to $100 \mu \mathrm{m}$ and appear too large for such an interpretation.

The occurrence of zebra limestone and laminated muds, in cases with stromatolitic textures in the upper part of the microbialite body is taken as further evidence for the activity of microbes. In the case of the zebra limestones, cement formation took place in between microbial mats that had a considerable component of trapping and binding as seen in the occurrence of small bioclasts.

The micrite laminites and stromatolitic textures at the top of the microbialite body were likely caused by the activity of microbes as well. They resemble postglacial (Quaternary) cryptic microbialites in Quaternary reef systems (Heindel et al. 2010, 2012; Braga et al. 2019). In the laminated framework at the top of the microbialite body, remains of "keratose" demosponges are very common. As demonstrated by
Luo and Reitner (2016), these sponges may form stromatolite-like, i.e., organically laminated build-ups, in that they produce micrite during microbial degradation of sponge tissue. The occurrence of small shells and shell debris from mollusks, tentaculitids, and ostracods and other invertebrates both in the reticulate and the laminated framework of the microbialite body, including the zebra limestone, supports the contention that trapping and binding of biodetrital material was another important source of carbonate accretion in addition to the biotically-triggered precipitation in general. This has been observed to various degrees in modern cryptic reef microbialites also (Reitner et al. 1995; Gischler et al. 2017, 2020).

Alternatively, some of the deposits of the laminated framework, including the Ursoscopulus stromatolites, could be interpreted as micritic sedimentary infills in submarine fractures and/or cave environments. Weller (1995) used the term "endostromatolite", which was introduced by Monty (1982). Although there is no clear definition of endostromatolites, there is an agreement that most endostromatolites are cryptic and often formed by iron-rich microbialites like Frutexites and comparable structures. A clear microbial fabric of Frutexites is questionable (e.g., Böhm and Brachert 1993), as discussed above, however, recent work on modern analoga suggests a microbial origin (Heim et al. 2017). The term has been used also to describe stromatolitic fabrics in calcrete (Pellerin et al. 2009). The layers of the Rübeland structure exhibit grading, burrows, putative fecal pellets, and remains of filamentous skeleton networks of "keratose" sponges. Some of the sedimentary layers exhibit early diagenetic cement crusts, which are maybe related to former biofilms (Reitner 2011) developed on the very dense micritic layers. Some of the micrite layers are red-colored, and Weller (1995) suggested Fe-oxidizing bacteria, however, no remains of bacteria could be found except for some Frutexites colonies (see Fig. 12F). The red-colored micrite could be a diagenetic product of the oxidation of ferrous iron species like fine-grained pyrite, which is seen in dark gray-colored micrite based on Raman analysis.

The fact that indications of slumping and sliding as well as multiple geopetals in the upper part of the microbialite body are found, suggests synsedimentary movement of the microbial sediment, including sponge bodies, possibly caused by seismic events in the late phase of the reef cave. Volcanic activity largely occurred during the mid Devonian (Weller 2003, 2008), but later seismic activity at the reef basement cannot be excluded as evidenced by the occurrence of late Devonian neptunian dikes.

The observation that conodonts are not as common in the upper part of the microbialites could indicate a progressive separation of the reef cave and the open ocean, e.g., by choking or blocking of the cave entrance with debris. Alternatively, the laminated deposits exposed at Bear Rock 

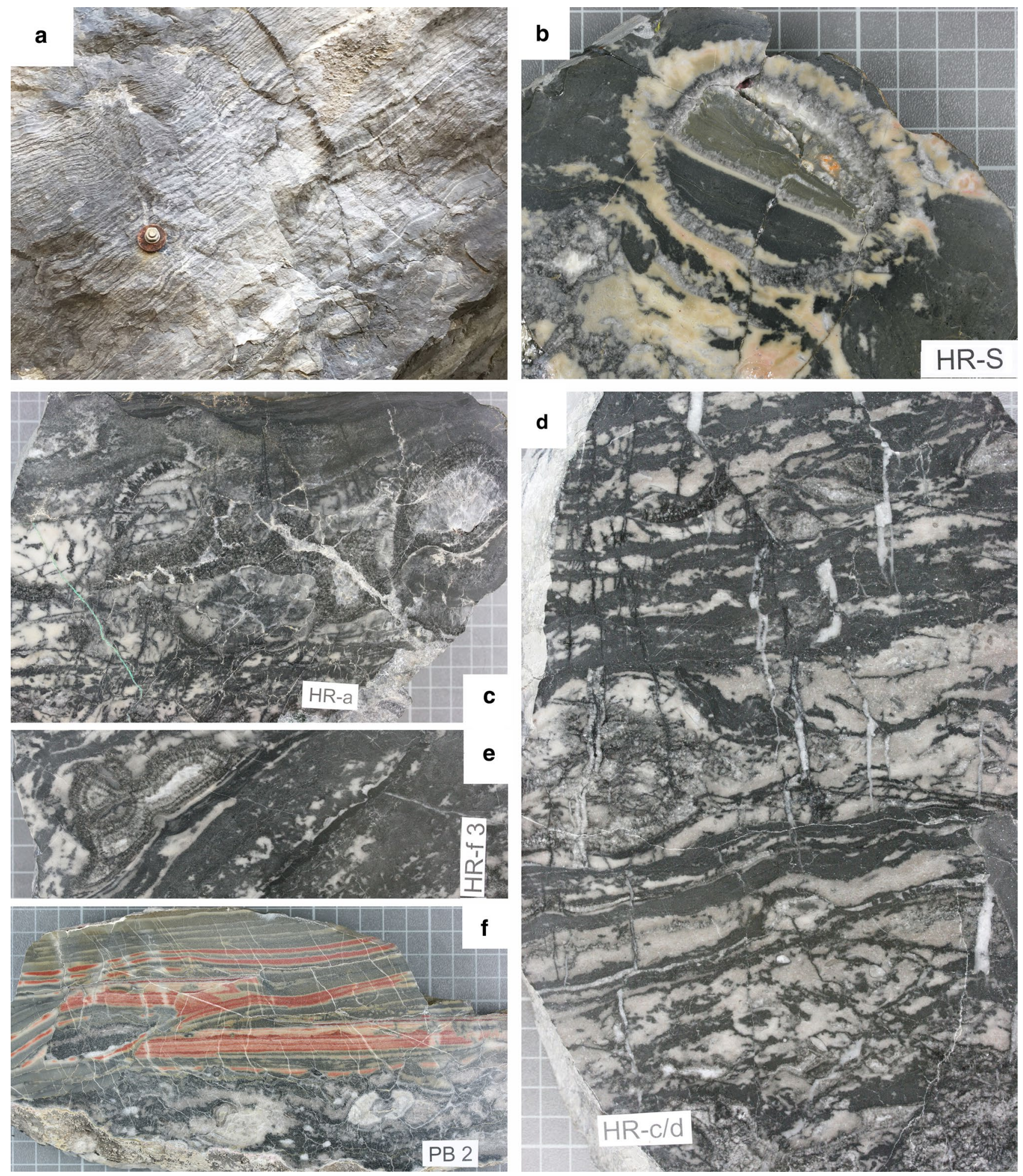

Fig. 7 Outcrop photo and polished hand specimens of zebra limestone and reticulate textures with large sponge body fossils. a Zebra limestone outcrop above old Cave Restaurant. Scale: screw and washer have $2 \mathrm{~cm}$ diameter. b Well-preserved sponge body fossil (hexactinose hextactinellid) from Cave Restaurant area. Note two generations of inclined, internal sediment filling the sponge. Remaining cavity filled with fibrous and dogtooth cements. c Moderately

well-preserved sponge body fossils in sample HR a from Cave Restaurant. Note dark gray filling of neptunian dike at top. d Reticulate microbial framework with cross section through large sponge body fossil (left, center). e Fine-grained carbonate and stromatactoid cavity in sample HR f3. f Largely reticulate microbialite containing shell of gonatite overlain by laminated facies. Scale of grid in background is $1 \mathrm{~cm}$ 



Fig. 8 Outcrop and polished hand specimens showing laminated microbial framework. a Outcrop photo of bulbous stromatolite from Bear Rock. Hammer for scale. b Texture of alternating light and dark gray layers from Bear Rock; sample BF 1. c Sample BF 6 exhibiting the effects of slumping and sliding. $\mathbf{d}$ Regularly laminated facies from

transitional between Cave Restaurant and Bear Rock. e Laminated texture of microbialite in neptunian dike; sample from old entrance of Cave Baumann. f Laminated texture in microbialite from northern slope of Bode valley. Scale of grid in background is $1 \mathrm{~cm}$

could represent the cave deposits most distal to the former cave entrance (Fuchs 1986). Only the finest detrital sediment was deposited along with few conodonts, which are characterized by relatively high density. The relatively short-lived character and the temporal restriction of the microbial carbonates of the Elbingerode Reef Complex to one conodont zone can be easily explained by the submarine cave model. The microbialites apparently started to form after the cavity had formed and ceased to accumulate when the submarine cave was filled with sediment, i.e., when there was no more accommodation space available.

A previous investigator interpreted the Rübeland microbialite as a mound (Weller 1989a, b, 1995), and the microbialite body indeed shares some textural characteristics with classical mud mounds that developed in moderately deep to deep water such as abundant micrite and stromatactis 

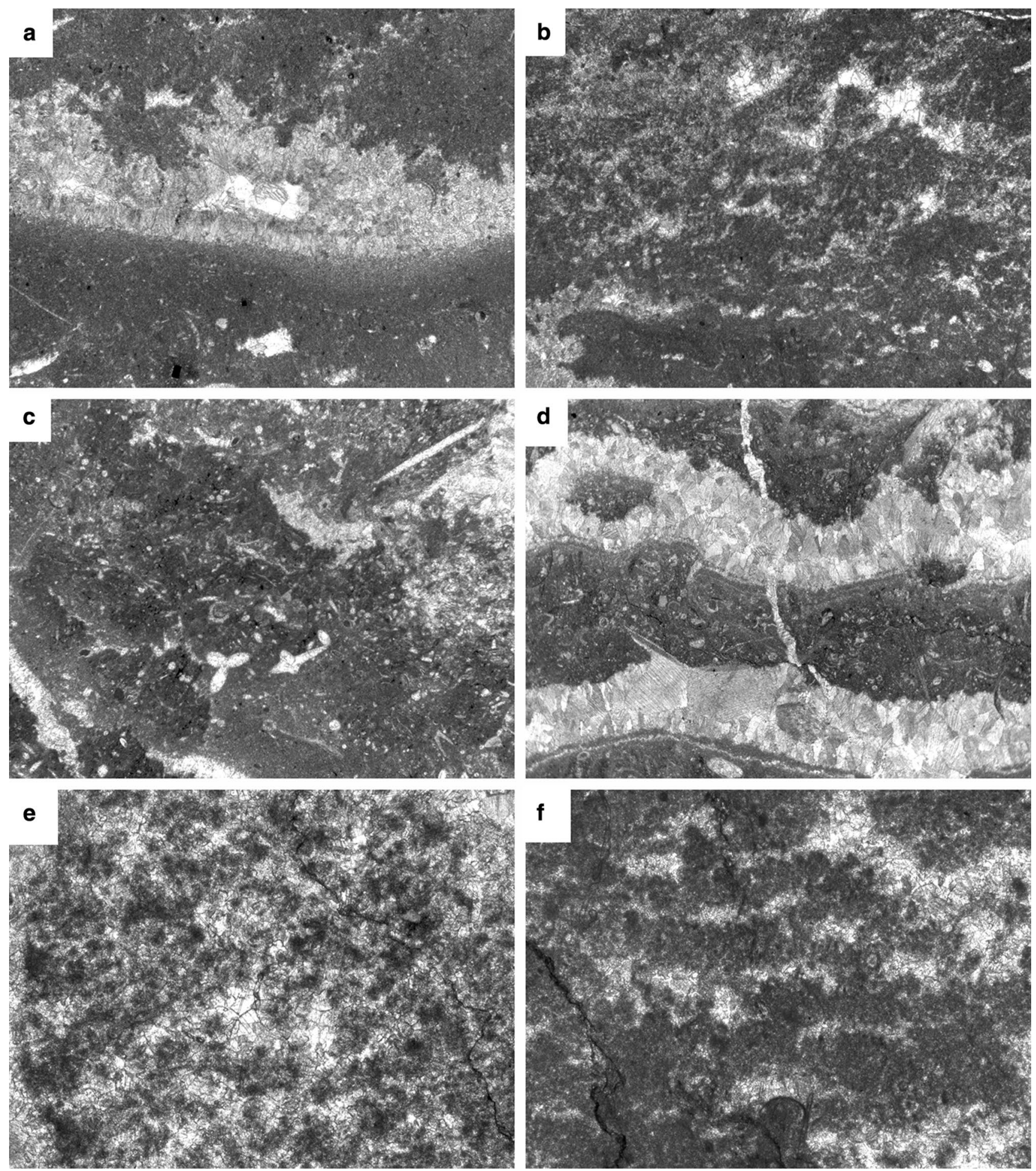

Fig. 9 Thin-section micrographs from the reticulate microbial framework including zebra limestone and sponge body fossils. a Stromatactis in fine-grained carbonate. Note that cavity is filled with fibrous and blocky cements. Sample K 1 . Width of picture is $9 \mathrm{~mm}$. b Reticulate texture in sample $\mathrm{K} 1$. Width of picture is $9 \mathrm{~mm}$. c Note biode-

tritus including conspicuous sponge needles in sample S 2. Width of picture is $9 \mathrm{~mm}$. d Zebra limestone of sample HR f2. Note biodetritus in fine-grained carbonate. e, f Peloidal ("spongiform") textures visible in area of former hexactinellid sponge tissue; sample HR a. Widths of pictures is $4.5 \mathrm{~mm}$ 

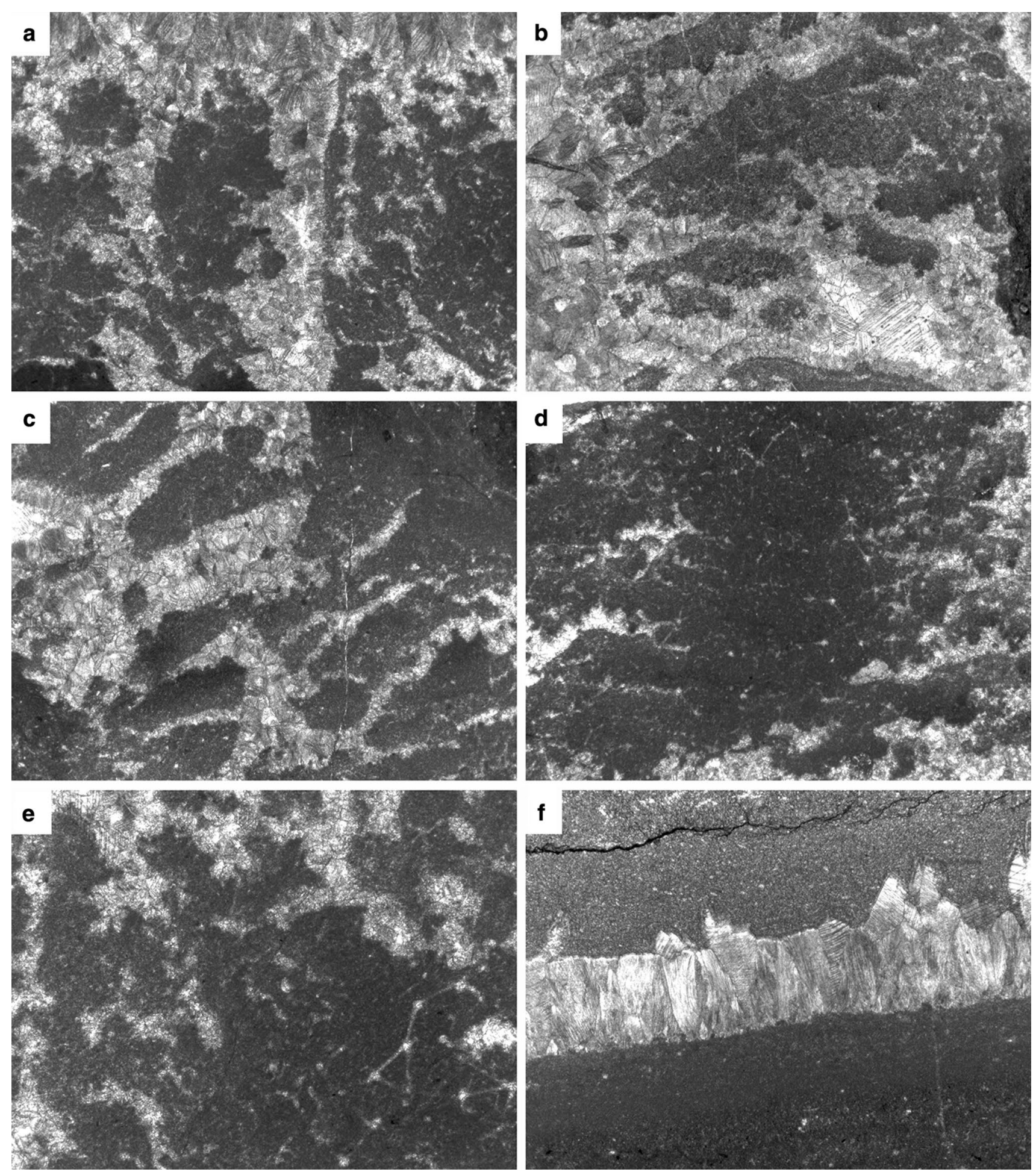

Fig. 10 Thin-section micrographs of large sponge body fossils in sample HR-S. a-c Stromatactoid textures in area of former sponge tissue. Widths of pictures is $9 \mathrm{~mm}$. d Fine grained carbonate and stromatactoid cavities in sponge wall area showing coalescing sponge

needles. Width of picture $9 \mathrm{~mm}$. e Same area. Width of picture is $4.5 \mathrm{~mm}$. $\mathbf{f}$ Two generations of internal sediment within spongocoel separated by fibrous cement crust. Width of picture is $9 \mathrm{~mm}$ 

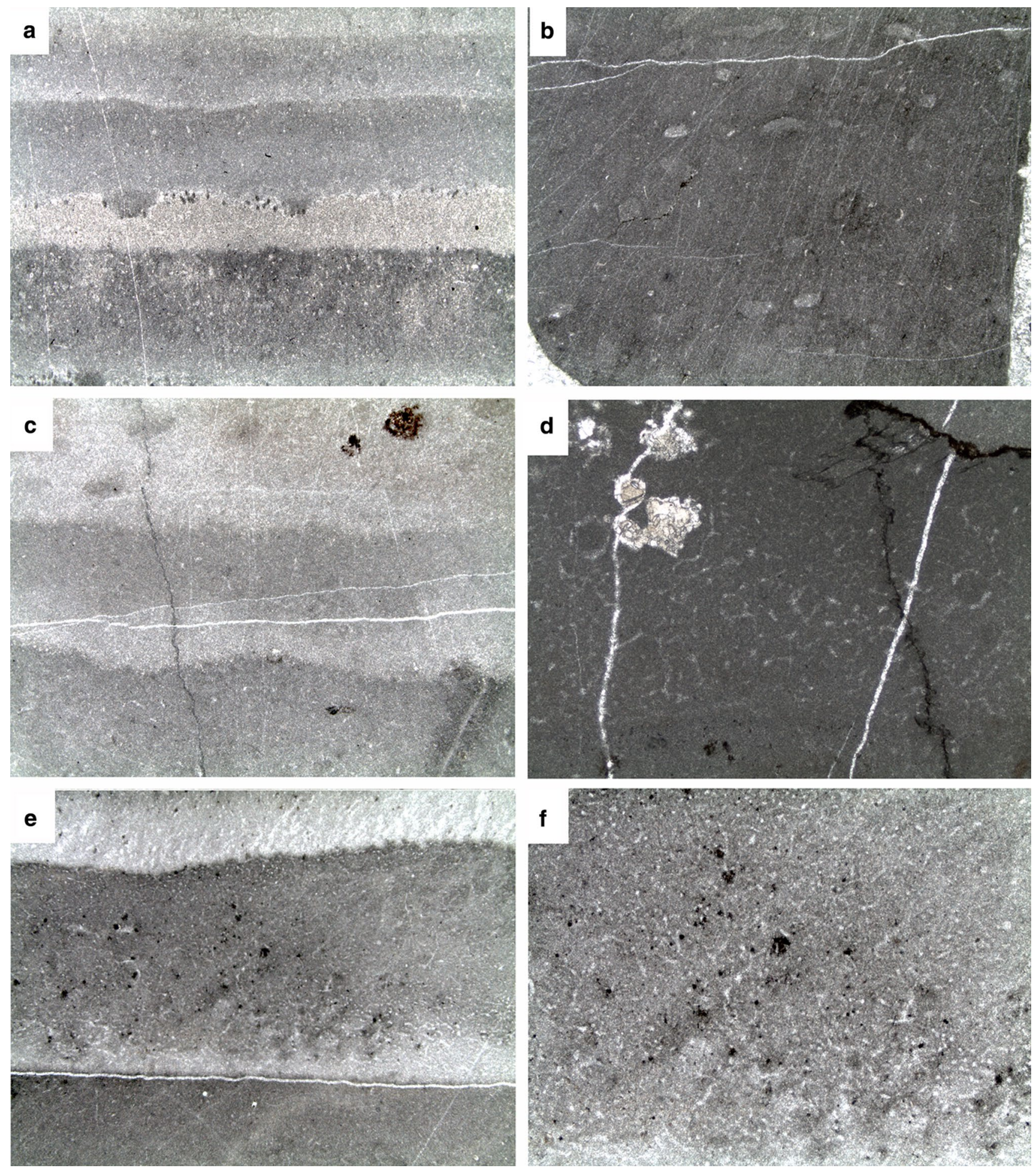

Fig. 11 Thin-section micrographs from the laminated microbial framework. a Laminae in sample BF 1. Note that peloids are seen at layer boundary in center of picture. Lowermost layer contains few bioclasts. Width of picture is $9 \mathrm{~mm}$. b Indications of bioturbation in sample BF 2. Width of picture is $9 \mathrm{~mm}$. c Laminae exhibit upward fining as seen in increasing dark stains towards upper parts of lami-

nae. Width of picture is $9 \mathrm{~mm}$. d Framework of anastomosing "keratose" sponge spicules. Sample BF 6. Width of picture is $4.5 \mathrm{~mm}$. e, f "Keratose" sponge framework in sample HR-BF 1. Also note dark shreds of likely organic matter. Width of picture is $9 \mathrm{~mm}$ in E, and $4.5 \mathrm{~mm}$ in $\mathrm{F}$ 

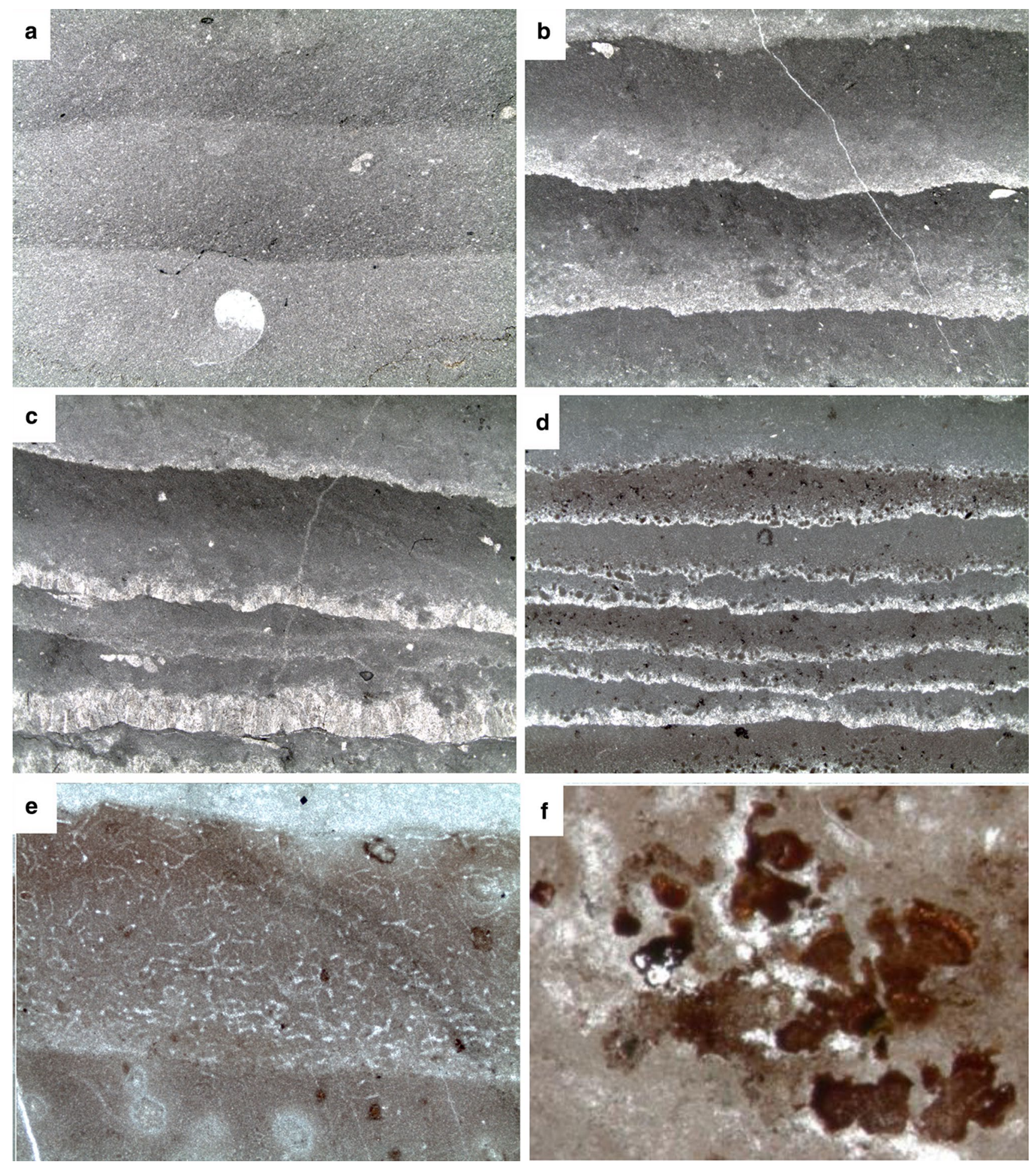

Fig. 12 Thin-section micrographs from the laminated microbial framework. a Regular laminae in neptunian dike at old entrance of Cave Baumann. Width of picture is $9 \mathrm{~mm}$. b Upward fining in laminae of sample BM. Width of picture is $9 \mathrm{~mm}$. c Fibrous cement crusts at bases of laminae in sample BM. Width of picture is $4.5 \mathrm{~mm}$. d

Peloids in laminae of sample PB 2. e "Keratose" sponge framework in layers of sample PB 2. Width of picture is $9 \mathrm{~mm}$. f Characterisitic digitate Frutextites embedded in a red micrite layer. Bear Rock locality. Width of picture is $5.5 \mathrm{~mm}$ 
Table 3 Carbonate content of selected samples based on X-ray diffractometry

\begin{tabular}{lllll}
\hline Sample & $\begin{array}{l}\text { Aragonite } \\
\text { rel. \% }\end{array}$ & $\begin{array}{l}\text { High-Mg } \\
\text { calcite rel. \% }\end{array}$ & $\begin{array}{l}\text { Low-Mg } \\
\text { calcite rel. \% }\end{array}$ & Quartz \% \\
\hline BF 6 & 0 & 0 & 100 & 2.1 \\
HR-BF 1 & 0 & 0 & 100 & 4.4 \\
S 1 & 0 & 0 & 100 & 1.6 \\
K 1 & 0 & 0 & 100 & 1.2 \\
PB 1-1 & 0 & 0 & 100 & 2.5 \\
PB 2 & 0 & 0 & 100 & 0 \\
PB 1 Riff & 0 & 0 & 100 & 0 \\
PB 2 Riff & 0 & 0 & 100 & 1.2 \\
HR-a & 0 & 0 & 100 & 1.2 \\
\hline
\end{tabular}

textures. However, the formation of a muddy topographic high on the sea floor in open water on a relatively highenergy stromatoporoid-coral fore-reef slope with high sedimentation rates appears rather unlikely, first and foremost because of the abundance of micrite. Based on the paleogeographic setting and following the facies distribution in the nearby Iberg Reef (Gischler 1995), the southeastern forereef slope of the Elbingerode Reef Complex likely represented the windward reef margin. Modern fore-reef slopes are usually characterized by coarse-grained, grain-supported textures (James and Ginsburg 1979). Microbial formations on late Devonian reef slopes were found in the Canning Basin of northwestern Australia (George 1999; Webb 2001). However, these shallower examples are also rather grainy and lack stromatolites and are dominated by calcimicrobes and considerable amounts of cement crusts (Webb 2001).
In deeper-water Australian examples, columnar and domal stromatolite bodies up to tens of meters in diameter were described that contain an accessory fauna of crinoids, corals, mollusks, brachiopods, and sponges (George 1999). Water depths remained poorly constrained, as they are apparently in the classical mud mounds the paleobathymetry of which was recently challenged by Hebbeln and Samankassou (2015). The depositional environment of the deeper Canning Basin fore-reef examples was interpreted as being characterized by protected areas with very low sedimentation rates, e.g., on downslope sides of talus blocks (George 1999). Also, most of the Australian occurrences are Famennian, only few are late Frasnian in age, when carbonate production by stromatoporoid and coral hypercalcifiers was almost completely shut down. This is not the case for the early Frasnian example of the Elbingerode Reef Complex.

For the latter, we envision a depositional environment such as a larger cave or blue hole-like setting on the windward fore-reef slope that protected the microbialites of the Elbingerode Reef Complex from high-energy, open-water sedimentation (Fig. 16). It would be altogether fitting that deep-water sponges such as the hexactinose hexactinellids and other sponges were dwelling in a shallower-water reef cavity. The origin of the submarine cave would most likely have been a growth or framework cavity. A larger groove within a spur-and-groove system that was later modified could have been a starting point of the growth cavity. Alternatively, a wide neptunian dike could have been the origin. Both spurs and grooves have been shown to exist already in Devonian fore-reef settings (Wood and Oppenheimer 2000) and neptunian dikes occur in the Elbingerode Reef Complex as discussed above. True blue hole formation is not as likely,
Fig. 13 Cross plot of oxygen and carbon stable isotope data from Rübeland microbialite and adjacent rocks

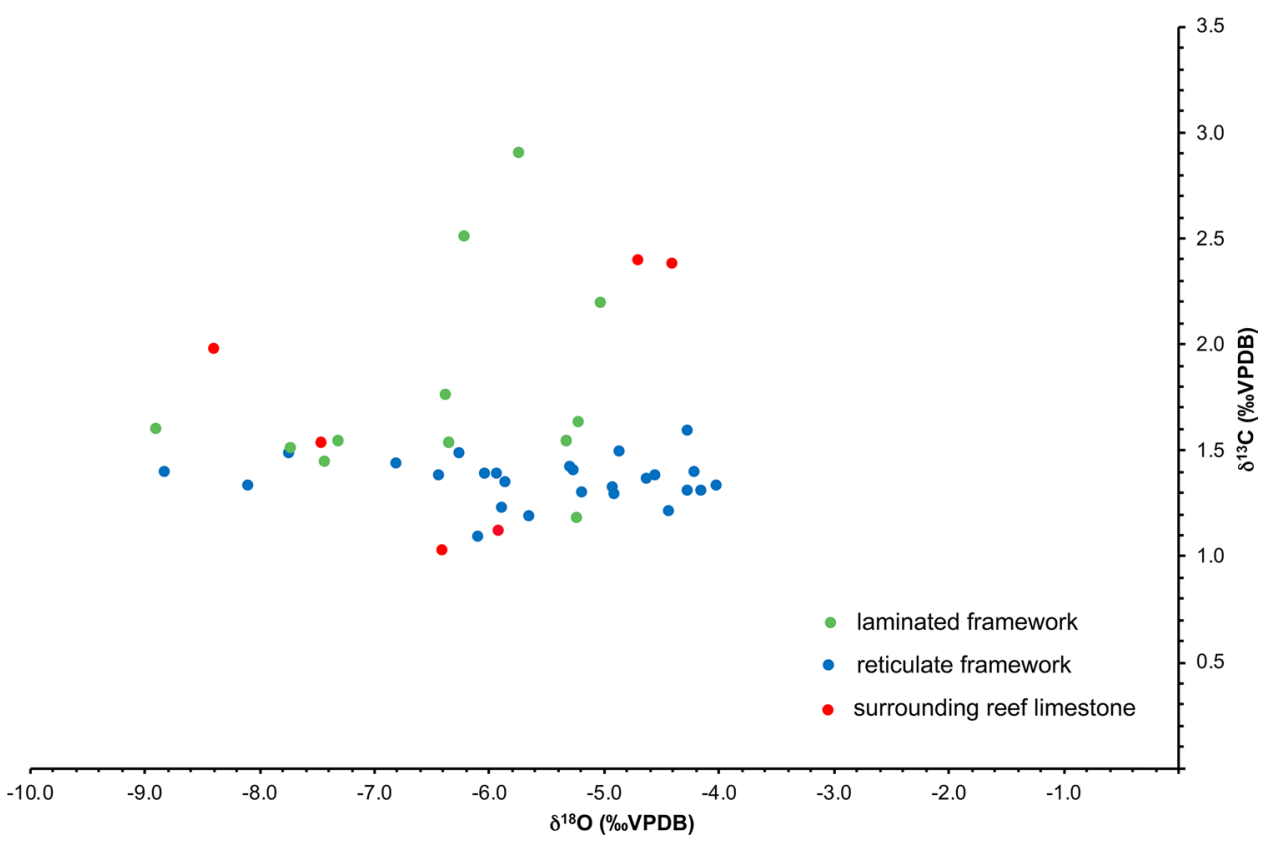



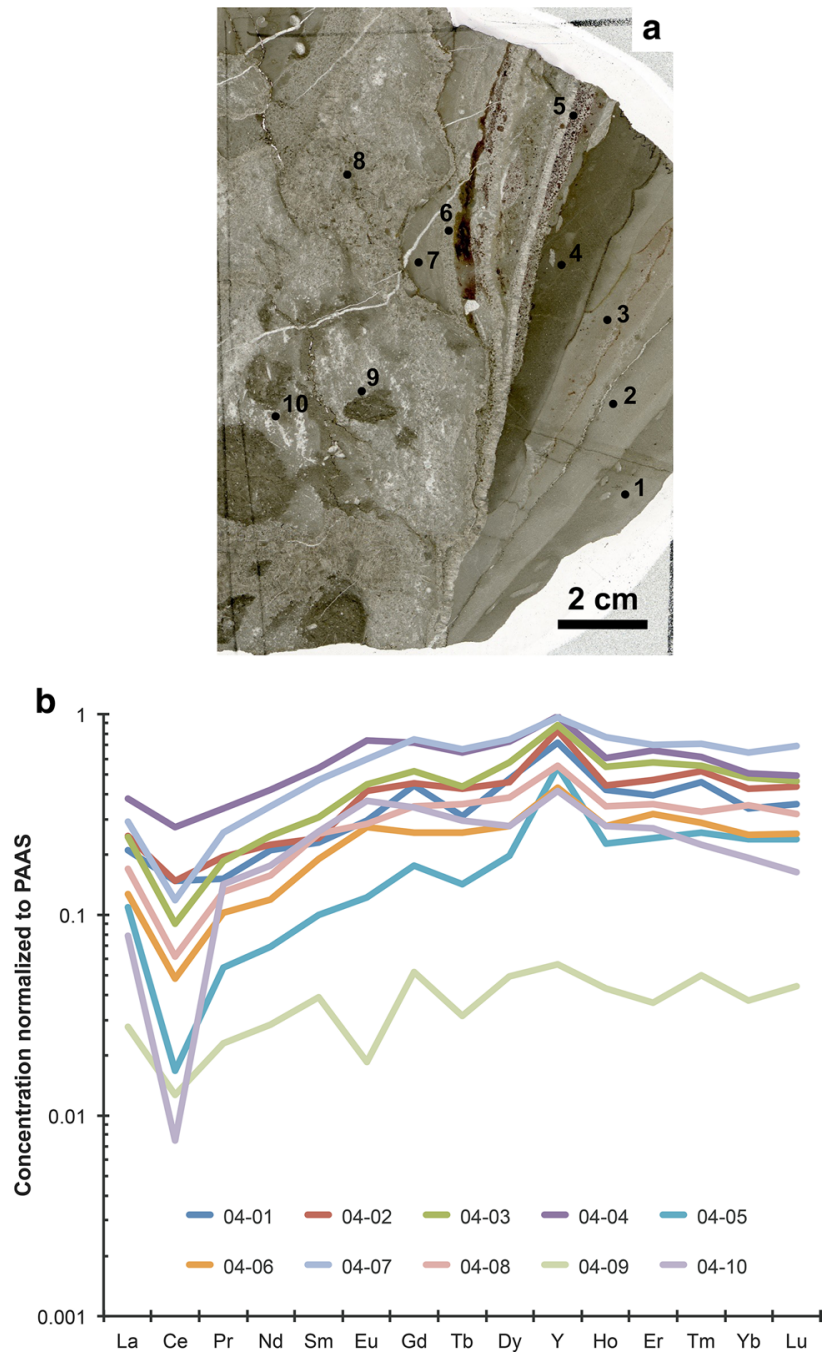

Fig. 14 a Polished sample Rü 4 with the locations of the ten subsamples for trace element analysis. b REE\&Y patterns of ten domains in sample Rü 4. Same domains (most notably domain 04) show minor enrichment in mid-REE and a less pronounced Ce anomaly. Post Archean Average Shale (PAAS) values are from Taylor and McLennan (1985)

because it could have occurred only via karst processes during a longer sea-level lowstand and subaerial exposure of the Elbingerode Reef Complex prior to microbialite formation in the Givetian or early Frasnian. High-amplitude, glacioeustatic sea-level changes are unlikely during the mid to early late Devonian greenhouse climate, which was probably lacking polar ice shields. The sea-level curve of Haq and Schutter (2008) shows a second-order rise during the Givetian, peaking in the early Frasnian, and a fall during the Frasnian. Superimposed third-order and fourth-order changes in sea level have occurred repeatedly during this time window, the latter especially during the Givetian, which could have potentially exposed the Elbingerode Reef Complex. However, the absolute amplitudes of these third-order

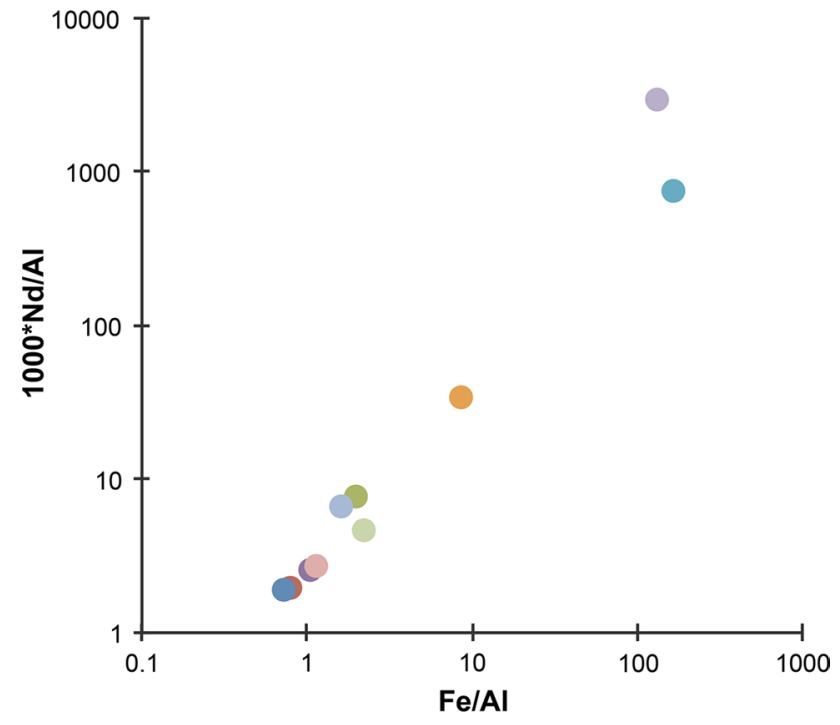

Fig. 15 Mass ratios of $\mathrm{Nd} / \mathrm{Al}$ plotted versus $\mathrm{Fe} / \mathrm{Al}$. Normalization to $\mathrm{Al}$ removes potential effects of clay impurities in the calcite. The positive correlation indicates that $\mathrm{Nd}$ (representative of mid-REE) is enriched in domains rich in Fe. Color coding as in Fig. 14

and fourth-order falls are largely unknown and clear sedimentological evidence for Givetian-Frasnian subaerial exposure and karst in the Elbingerode Reef Complex are lacking. Also, the processes driving high-frequency sea-level cycles in an ice-free world are largely unknown. For mid and late Cretaceous times, which are characterized by a greenhouse climate and a lack of polar ice shields as well, sedimentological evidence for sea-level change has been explained by continental water storage in and from aquifers and lakes (Sames et al. 2016; and references therein). Such changes certainly had only relatively low amplitudes as compared to Quaternary glacio-eustasy.

Some of the geochemical data may be used to support the described model of cryptic microbial carbonate formation. The fact that magnesium contents of the microbialites are significantly higher as compared to surrounding stromatoporoid-coral reef limestones (Oesterreich 1991) might be a hint to initially higher contents of magnesium and the existence of high-magnesium calcite. Modern and late Quaternary reef microbialites characteristically consist by considerable parts of high-magnesium calcite (Reitner 1993; Reitner et al. 1995; Montaggioni and Camoin 1993; Heindel et al. 2010; Gischler et al. 2017, 2020). Van Lith et al. (2003) have observed that sulfate-reducing bacteria apparently exert control on calcium carbonate polymorph mineralogy in that high-magnesium calcite and dolomite precipitation occurred preferentially both experimentally and in a modern, hypersaline coastal lagoon. Ries (2010) reported that the magnesium content varied in calcium carbonate precipitates of microbial mats dominated by cyanobacteria according to $\mathrm{Mg} / \mathrm{Ca}$-ratios 


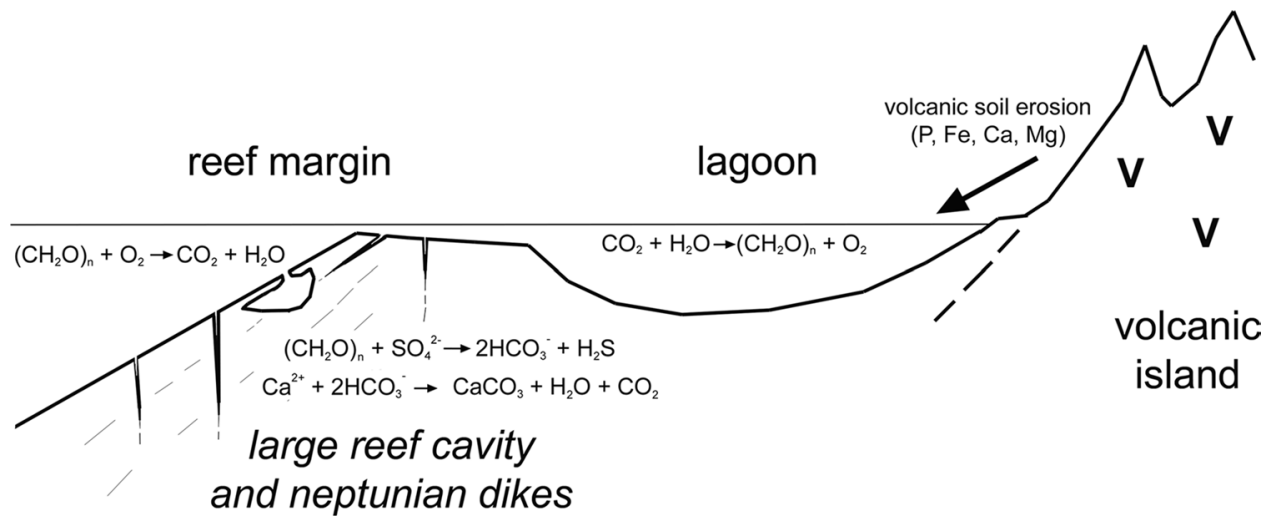

Fig. 16 Tentative sketch showing the principal depositional setting of the Elbingerode Reef Complex as an oceanic barrier reef system (only southeastern, windward reef, lagoon and parts of central volcanic island shown), including a large reef cavity in the former forereef slope along with the occurrence of neptunian dikes. Nutrients $(\mathrm{P}$, $\mathrm{Fe}$ ) as well as $\mathrm{Ca}$ and $\mathrm{Mg}$ are brought into the system from weather-

in ambient waters. However, high-magnesium calcite precipitation prevailed in high, moderate, and low $\mathrm{Mg} / \mathrm{Ca}$-ratio waters, i.e., even in artificial seawater of "calcite seas" like in the Devonian. In the case of the Rübeland microbialite body, diagenetic alteration has transformed possible metastable high-magnesium calcite and aragonite to low-magnesium calcite.

Stable isotopes of oxygen and carbon fall in the field of average marine limestones. There are no patterns and significant differences among facies and microbialites and surrounding reef limestones. Also, there are no significantly negative $\delta^{13} \mathrm{C}$ values, which would indicate a methane-seep influence as seen in post-reefal brachiopod and microbialite deposits of the adjacent mid-late Devonian Iberg Reef further to the west (Gischler 1996; Peckmann et al. 2001).

Rare earth element and Y patterns show explicitly negative Ce-anomalies and positive $\mathrm{Y}$-anomalies indicative of typical marine carbonates that form under oxic conditions in environments where remineralization of organic carbon compounds plays a minor role. However, the generally elevated REE levels may indicate some diagenetic influence on pore water composition. Some domains of the sample analyzed show minor enrichment of mid-REE, which has also been detected in seep carbonates (e.g., Himmler et al. 2010). However, an enrichment of light REE, which is perhaps most indicative of environments dominated by the remineralization of organic compounds (e.g., Neuweiler et al. 2003; Smrzka et al. 2019), is lacking. The generally high REE contents and the mid-REE bulge in the patterns may indicate that $\mathrm{Fe}$-oxyhydroxide dissolution released REE to the pore water pool prior to calcite formation (e.g., Haley et al. 2004). This possibility is corroborated by the midREE neodymium, the concentration of which appears to be ing of central volcanic islands. Primary producers likely perform photosynthesis in surface waters including barrier-reef lagoon. Organic matter is likely consumed in reef cavities by heterotrophic organisms including sulfate-reducing bacteria. Microbial carbonate eventually precipitates in cavities

correlated with Fe-contents. The possible extent of Fe-oxyhydroxide dissolution driven by dissimilatory iron reduction fueled by organic carbon compounds was minor as indicated by the seawater-like $\delta^{13} \mathrm{C}$ values of the calcite. By the same token, we can rule out that Fe-reduction was coupled to the anaerobic oxidation of methane (AOM). In summary, the negative $\mathrm{Ce}$-anomaly and positive $\mathrm{Y}$-anomaly are indicative of calcite formation shallow in the system, where the porewaters retain the seawater signature and conditions are not permanently anoxic. Mid-REE and Fe enrichments in some of the domains may be indicative of suboxic episodes in the history of microbialite formation.

\section{Conclusions}

The following major findings were made during the revisit of the conspicuous late Devonian (Frasnian) microbialite occurrence in Rübeland, Elbingerode Reef Complex, Harz Mountains, Germany.

- The microbialite of the Elbingerode Reef Complex is composed of large amounts of fine carbonate and consists of a reticulate and a laminated framework. The former contains abundant stromatactis. Zebra limestone is moderately common.

- Sponges are abundant and represent a significant element of the microbialites in that bacterial decay processes of hexactinose glass sponges and "keratose" demosponges appear to have been crucial during carbonate formation.

- Geochemical data suggest that the microbialites of the Elbingerode Reef Complex initially largely consisted of 
high-magnesium calcite. REE $+\mathrm{Y}$ data indicate deposition under oxic conditions with suboxic episodes.

- Unlike previous interpretations of a mound setting, we suggest that the microbialites of the Elbingerode Reef Complex formed in a large cavity of the fore-reef slope of an oceanic barrier reef system. In analogy to modern occurrences, microbial carbonate formation in the Elbingerode Reef Complex was likely to a large part induced by the activity of sulfate-reducing and some cryptic calcimicrobes and further fertilized by weathering products from the central volcanic islands of the reef system.

\begin{abstract}
Acknowledgements We thank Gabriela Meyer (Frankfurt) for help during sampling. Holger Fraustein (Rübeland) gave permission to collect the samples and provided the two short cores from the ground floor of the old Cave Restaurant building. Nils Prawitz and Daniel Parwareschnia (Frankfurt) cut and polished the samples. N. Prawitz also made the thin-sections. Diana Diers, Rainer Petschick, and Sven Hofmann (Frankfurt) are thanked for preparing and analyzing the XRD and isotope samples. Daniel Birgel (Hamburg) prepared and analyzed one sample for lipid biomarker analysis. We are grateful to journal reviewers Juan Carlos Braga (Granada) and Robert Riding (Knoxville) for their thoughtful comments, which improved this paper.
\end{abstract}

Funding Open Access funding enabled and organized by Projekt DEAL.

Open Access This article is licensed under a Creative Commons Attribution 4.0 International License, which permits use, sharing, adaptation, distribution and reproduction in any medium or format, as long as you give appropriate credit to the original author(s) and the source, provide a link to the Creative Commons licence, and indicate if changes were made. The images or other third party material in this article are included in the article's Creative Commons licence, unless indicated otherwise in a credit line to the material. If material is not included in the article's Creative Commons licence and your intended use is not permitted by statutory regulation or exceeds the permitted use, you will need to obtain permission directly from the copyright holder. To view a copy of this licence, visit http://creativecommons.org/licenses/by/4.0/.

\section{References}

Aehnelt, M., and H. Weller. 2004. Die ältesten Kalke im Elbingeröder Riffkomplex (Harz): Conodontenstratigraphische Datierung einer Vorphase der Riffentwicklung. Senckenbergiana Lethaea 84: 195-223

Ahlbrecht, J. 1997. Verkalkte Mikrobenrelikte und kryptische Habitate des Rübeland-Mikrobialiths (Elbingeröder Riffkomplex, Harz, Mittel-bis Oberdevon). 1-184. Unpublished Diploma thesis, University of Göttingen.

Aubrecht, R. 2011. Stromatactis. In Encyclopedia of geobiology, eds. J. Reitner and V. Thiel, 847-850. Berlin: Springer.

Böhm, F., and T. Brachert. 1993. Deep-water stromatolites and Frutexites Maslov from the early and middle Jurassic of S-Germany. Facies 28: 145-168.

Bourque, P.A., and F. Boulvain. 1993. A model for the origin and petrogenesis of the red Stromatactis Limestone of Paleozoic carbonate mounds. Journal of Sedimentary Petrology 63: 607-619.
Bourque, P.A., and H. Gignac. 1983. Sponge-constructed Stromatactis mud mounds, Silurian of Gaspé, Quebec. Journal of Sedimentary Petrology 53: 521-532.

Braga, J.C., A. Puga-Bernabeu, K. Heindel, M.A. Patterson, D. Birgel, J. Peckmann, I. Sachez-Almazo, J.M. Webster, Y. Yokoyama, and R. Riding. 2019. Microbialites in last glacial maximum and deglacial reefs of the Great Barrier Reef (IODP Expedition 325, NE Australia). Palaeogeography, Palaeoclimatology, Palaeoecology 514: $1-17$

Brunton, F.R., and O.A. Dixon. 1994. Siliceous sponge-microbe biotic associations and their recurrence through the Phanerozoic as reef mound constructors. Palaios 9: 370-387.

Copper, P. 2002. Silurian and Devonian reefs: 80 million years of global greenhouse between two ice ages. In Phanerozoic reef patterns, eds. W. Kiessling, E. Flügel, and J. Golonka. SEPM Special Publication 72: 181-238.

Fisher, D.C., and M.H. Nitecki. 1982. Problems in the analysis of receptaculitid affinities. In Third North American Paleontological Convention, Proceedings 1, eds. B. Mamet and M.J. Copeland, 181-186. Toronto: Business and Economic Service.

Friedel, C.H., and C. Janssen. 1988. Structural investigations of the Paleozoic reef limestone in the Elbingerode Complex (Lower Harz, G.D.R.). Zeitschrift für Geologische Wissenschaften 16: 421-438.

Fuchs, A. 1986. Zur Biostratigraphie der Karbonatgesteine des Elbingeröder Komplexes (Harz) unter besonderer Berücksichtigung der Riffkalke auf der Grundlage von Conodonten, 1-293. Unpublished $\mathrm{PhD}$ thesis, University of Greifswald.

Fuchs, A. 1987. Conodont biostratigraphy of the Elbingerode Reef Complex, Harz Mountains. Acta Geologica Polonica 37: 33-50.

Fuchs, A. 1989. Remarks on the Middle/Upper Devonian boundary in the Elbingerode Reef Complex, Harz Mountains. Courier Forschungsinstitut Senckenberg 117: 267-273.

Fuchs, A. 1990. Character and termination of the Devonian reefs in the Harz Mountains (Elbingerode Complex, Germany). Facies 23: 97-108.

George, A.D. 1999. Deep-water stromatolites, Canning Basin, Australia. Palaios 14: 493-505.

Gischler, E. 1995. Current and wind induced facies patterns in a Devonian atoll: Iberg Reef, Harz Mts, Germany. Palaios 10: 180-189.

Gischler, E. 1996. Late Devonian-early Carboniferous deep-water coral assemblages and sedimentation on a Devonian seamount: Iberg Reef, Harz Mts., Germany. Palaeogeography, Palaeoclimatology, Palaeoecology 123: 297-322.

Gischler, E., A. Balinski, A. Fuchs, and D. Heidelberger. 2004. Famennian gastropod and brachiopod occurrences on top of Devonian seamounts: Elbingerode and Iberg reefs, Harz Mts, Germany. Senckenbergiana Lethaea 84: 125-139.

Gischler, E., D. Birgel, B. Brunner, and J. Peckmann. 2020. Microbialite occurrence and patterns in Holocene reefs of Bora Bora, Society Islands. Palaios 35: 262-276.

Gischler, E., K. Heindel, D. Birgel, B. Brunner, J. Reitner, and J. Peckmann. 2017. Cryptic biostalactites in a submerged karst cave of the Belize Barrier Reef revisited: Pendant bioconstructions cemented by microbial micrite. Palaeogeography, Palaeoecology, Palaeoclimatology 468: 34-51.

Grammer, G.M., R.N. Ginsburg, P.K. Swart, D.F. McNeill, A.J. Jull, and D.R. Prezbindowski. 1993. Rapid growth rates of syndepositional marine aragonite cements in steep marginal slope deposits, Bahamas and Belize. Journal of Sedimentary Petrology 63: 983-989.

Haq, B.U., and S.R. Schutter. 2008. A chronology of Paleozoic sealevel changes. Science 322: 64-68.

Haley, B.A., G.P. Klinkhammer, and J. McManus. 2004. Rare earth elements in pore waters of marine sediments. Geochimica et Cosmochimica Acta 68: 1265-1279. 
Hebbeln, D., and E. Samankassou. 2015. Where did ancient carbonate mounds grow-in bathyal depth or in shallow shelf waters? EarthScience Reviews 145: 56-65.

Heim, C., N.V. Queric, D. Ionescu, N. Schäfer, and J. Reitner. 2017. Frutexites-like structures formed by iron oxidizing biofilms in the continental subsurface (Äspo Hard Rock Laboratory, Sweden). PLoS ONE 12: E0177542. https://doi.org/10.1371/journal.pone. 0177542.

Heindel, K., D. Birgel, J. Peckmann, H. Kuhnert, and H. Westphal. 2010. Formation of deglacial microbialites in coral reefs off Tahiti (IODP 310) involving sulfate-reducing bacteria. Palaios 25: 618-635.

Heindel, K., D. Birgel, B. Brunner, V. Thiel, H. Westphal, S.B. Ziegenbalg, E. Gischler, G. Cabioch, and J. Peckmann. 2012. Post-glacial microbialite formation in coral reefs in the Pacific Ocean, Caribbean, and Indian Ocean. Chemical Geology 304-305: 117-130.

Himmler, T., W. Bach, G. Bohrmann, and J. Peckmann. 2010. Rare earth elements in authigenic methane-seep carbonates as tracers for fluid composition during early diagenesis. Chemical Geology 277: $126-136$

James, N.P., and R.N. Ginsburg. 1979. The seaward margin of Belize barrier and atoll reefs. IAS Special Publication 3: 1-191.

James, N.P., and R. Wood. 2010. Reefs. In Facies Models, 4, eds. N.P. James and D.W. Dalrymple, 421-447. St. Johns: Geological Association of Canada.

Janssen, C., C.H. Friedel, and H.J. Paech. 1990. Zur Frühdiagenese der devonischen Riffkalksteine des Elbingeröder Komplexes (Harz). Zeitschrift für Geologische Wissenschaften 18: 977-985.

Jonkers, L., A. Gopalakrishnan, L. Weßel, C. Chiessi, J. Groeneveld, P. Monien, D. Lessa, and R. Morard. 2021. Morphotype and crust effects on the geochemistry of Globorotalia inflata. Paleoceanography and Paleoclimatology 36: e2021PA004224. https://doi.org/ 10.1029/2021PA004224.

Kiessling, W., E. Flügel, and J. Golonka. 1999. Paleoreef Maps: Evaluation of a comprehensive database on Phanerozoic reefs. American Association of Petroleum Geologists Bulletin 83: 1552-1587.

Krebs, W. 1969. Early void-filling cementation in Devonian fore-reef limestones, Germany. Sedimentology 12: 279-299.

Krebs, W. 1974. Devonian carbonate complexes of Central Europe. In Reefs in time and space, ed. L.F. Laporte. SEPM Special Publication 18: 155-208.

Lee, J.H., and R. Riding. 2018. Marine oxygenation, lithistid sponges, and the early history of Paleozoic skeletal reefs. Earth-Science Reviews 181: 98-121.

Luo, C., and J. Reitner. 2014. First report of fossil "keratose" demosponges in Phanerozoic carbonates: Preservation and 3-D reconstruction. Naturwissenschaften 101: 467-477.

Luo, C., and J. Reitner. 2016. "Stromatolites" built by sponges and microbes-A new type of Phanerozoic bioconstruction. Lethaia 49: 555-570.

Mehl, D. 1996. Phylogenie und Evolutionsökologie der Hexactinellida (Porifera) im Paläozoikum. Geologisch-Paläontologische Mitteilungen Innsbruck, Sonderband 4: 1-55.

Milliman, J.D. 1974. Marine Carbonates, 1-375. Berlin: Springer.

Montaggioni, L.F., and G.F. Camoin. 1993. Stromatolites associated with coralgal communities in Holocene high-energy reefs. Geology 21: 149-152.

Monty, C.L.V. 1982. Cavity or fissure dwelling stromatolites (endostromatolites) from Belgian Devonian mud mounds (extended abstract). Annales de la Societé Géologique de Belgique 105: 343-344.

Mossop, G.D. 1972. Origin of the peripheral rim, Redwater Reef, Alberta. Bulletin of Canadian Petroleum Geology 20: 238-280.

Nance, R.D., G. Gutiérrez-Alonso, J.D. Keppie, U. Linnemann, J.B. Murphy, C. Quesada, R.A Strachan, and N.H. Woodcock. 2010. Evolution of the Rheic Ocean. In The Rheic Ocean: Palaeozoic evolution from Gondwana and Laurussia to Pangaea, ed. R.D. Nance. Gondwana Research 17: 194-222.

Neuweiler, F., V. d'Orazio, A. Immenhauser, G. Geipel, K.H. Heise, C. Cocozza, and T.M. Miano. 2003. Fulvic acid-like organic compounds control nucleation of marine calcite under suboxic conditions. Geology 31: 681-684.

Oesterreich, B. 1991. Geochemische Faziesanalyse devonischer Riffkarbonate des Elbingeröder Komplexes (Östliches Rhenoherzynikum, Harz), 1-311. Unpublished PhD thesis, University of Greifswald.

Peckmann, J., E. Gischler, W. Oschmann, and J. Reitner. 2001. An early Carboniferous seep community and hydrocarbon-derived carbonates from the Harz Mountains, Germany. Geology 29: 271-274.

Pellerin, A., D. Lacelle, D. Fortin, I.D. Clark, and B. Lauriol. 2009. Microbial diversity in endostromatolites (cf. fissure calcretes) and in the surrounding permafrost landscape, Haughton Impact Structure Region, Devon Island, Canada. Astrobiology 9: 807-822.

Pigott, J.D., and L.S. Land. 1986. Interstitial water chemistry of Jamaican reef sediment: Sulfate reduction and submarine cementation. Marine Chemistry 19: 355-378.

Pratt, B.R. 1982. Stromatolitic framework of carbonate mud-mounds. Journal of Sedimentary Petrology 52: 1203-1227.

Pratt, B.R. 1995. The origin, biota and evolution of deep-water mudmounds. In Carbonate mud mounds. Their origin and evolution, eds. C.L.V. Monty, D.W.J. Bosence, P.H. Bridges, and B.R. Pratt. IAS Special Publication 23: 49-123.

Pratt, B.R. 2001. Calcification of cyanobacterial filaments: Girvanella and the origin of lower Paleozoic lime mud. Geology 29: 763-766.

Reitner, J. 1993. Modern cryptic microbialite/metazoan facies from Lizard Island (Great Barrier Reef, Australia): Formation and concepts. Facies 29: 3-40.

Reitner, J. 2011. Biofilms. In Encyclopedia of geobiology, eds. J. Reitner and V. Thiel, 134-135. Berlin: Springer.

Reitner, J., P. Gautret, F. Marin, and F. Neuweiler. 1995. Automicrites in a modern marine microbialite. Formation model via organic matrices (Lizard Island, Great Barrier Reef, Australia). Bulletin de l'Institut Océanographique Monaco, Numeró Spécial 14: 237-263.

Riding, R. 1991a. Calcified cyanobacteria. In Calcareous algae and stromatolites, ed. R. Riding, 21-51. Berlin: Springer.

Riding, R. 1991b. Classification of microbial carbonates. In Calcareous algae and stromatolites, ed. R. Riding, 55-85. Berlin: Springer.

Riding, R., and A. Virgone. 2020. Hybrid carbonate: In situ abiotic, microbial and skeletal co-precipitates. Earth-Science Reviews 208: 103300. https://doi.org/10.1016/j.earscirev2020/103300.

Riding, R., S.M. Awramik, B.M. Winsborough, K.M. Griffin, and R.F. Dill. 1991. Bahamian giant stromatolites: Microbial composition of surface mats. Geological Magazine 128: 227-234.

Ries, J.B. 2010. Review: Geological and experimental evidence for secular variation in seawater $\mathrm{Mg} / \mathrm{Ca}$ (calcite-aragonite seas) and its effects on marine biological calcification. Biogeosciences 7: 2795-2849.

Ruchholz, K. 1989. Begründung und Bedeutung des Bode-Lineaments. Wissenschaftliche Zeitschrift der Ernst-Moritz-Arndt-Universität Greifswald, Mathematisch-Naturwissenschaftliche Reihe 38: 63-69.

Sames, B., M. Wagreich, J.E. Wendler, B.U. Haq, C.P. Conrad, M.C. Melinte-Dobrinescu, X. Hu, I. Wendler, E. Wolfgring, I.Ö. Yilmaz, and S.O. Zorina. 2016. Review: Short-term sea-level changes in a greenhouse world-A view from the Cretaceous. Palaeogeography, Palaeoclimatology, Palaeoecology 441: 393-411.

Schlager, W. 2000. Sedimentation rates and growth potential of tropical, cool-water and mud-mound carbonate systems. In Carbonate platform systems: Components and interactions, eds. E. Insalaco, P. Skelton, and T.J. Palmer. Geological Society of London, Special Publication 178: 217-227. 
Smrzka, D., J. Zwicker, D. Misch, C. Walkner, S. Gier, P. Monien, G. Bohrmann, and J. Peckmann. 2019. Oil seepage and carbonate formation: A case study from the southern Gulf of Mexico. Sedimentology 66: 2318-2353.

Spötl, C., and T. Vennemann. 2003. Continuous-flow isotope ratio mass spectrometric analysis of carbonate minerals. Rapid Communications in Mass Spectrometry 17: 1004-1006.

Suosaari, E.P., R.P. Reid, P.E. Playford, J.S. Foster, J.F. Stolz, G. Casaburi, P.D. Hagan, V. Chirayath, I.G. Macintyre, N.J. Planavsky, and G.P. Eberli. 2016. New multi-scale perspectives on the stromatolites of Shark Bay, Western Australia. Scientific Reports 6: 20557. https://doi.org/10.1038/srep20557.

Tait, J.A., V. Bachtadse, W. Franke, and H.C. Soffel. 1997. Geodynamic evolution of the European Variscan fold belt. Geologische Rundschau 86: 585-598.

Taylor, S.R., and S.M. McLennan. 1985. The continental crust: Its composition and evolution. An examination of the geochemical record preserved in sedimentary rocks, 1-328. Oxford: Blackwell.

Turner, E.C. 2021. Possible poriferan bodyfossils in early Neoproterozoic reefs. Nature. https://doi.org/10.1038/s41586-021-03773-z.

Van Lith, Y., R. Warthmann, C. Vasconselos, and J.A. McKenzie. 2003. Sulphate-reducing bacteria induce low-temperature Ca-dolomite and high Mg-calcite formation. Geobiology 1: 71-79.

Webb, G.E. 1996. Was Phanerozoic reef history controlled by the distribution of nonenzymatically secreted reef carbonates (microbial carbonate and biologically induced cement)? Sedimentology 43: 947-971.

Webb, G.E. 2001. Famennian mud-mounds in the proximal core-reef slope, Canning Basin, Westerns Australia. Sedimentary Geology 145: 295-315.
Weller, G.H. 1989a. Sedimentologie von Mud Mounds und ihr Nachweis im Harz. Wissenschaftliche Zeitschrift der Ernst-MoritzArndt-Universität Greifswald, Mathematisch-Naturwissenschaftliche Reihe 38: 70-78.

Weller, H. 1989b. Das Rübeländer Mud Mound im Riffkomplex von Elbingerode (Harz) und seine sedimentologischen Eigenschaften. Hercynia (Neue Folge) 26: 321-337.

Weller, H. 1991. Facies and development of the Devonian (Givetian/ Frasnian) Elbingerode Reef Complex in the Harz area (Germany). Facies 25: 1-50.

Weller, H. 1995. The Devonian mud mound of Rübeland in the Harz Mountains/Germany. In Mud mounds: A polygenetic spectrum of fine-grained carbonate buildups, eds. J. Reitner and F. Neuweiler. Facies 32: 43-49.

Weller, H. 2003. Anmerkungen zur Devon-Korrelationstabelle, R 078 di-ds 03: Lithostratigraphie im Devon und Unterkarbon des Elbingeröder Komplexes (Harz) - ein Überblick. Senckenbergiana Lethaea 83: 199-204.

Weller, H. 2008. Elbingeröder Komplex. In Stratigraphie von Deutschland VIII. Devon, ed. Deutsche Stratigraphische Kommission. Schriftenreihe der Deutschen Gesellschaft für Geowissenschaften 52: 525-531.

Weller, H., and D. Mucke, 2014. Geologische Karte Elbingeröder Komplex 1:25.000. In Geologisch-Montanhistorische Karte Elbingeröder Komplex, eds. K. Stedingk, and I. Rappsilber. Halle/S.: Landesamt für Geologie und Bergwesen Sachsen-Anhalt.

Wood, R., and C. Oppenheimer. 2000. Spur and groove morphology from a late Devonian reef. Sedimentary Geology 133: 185-193.

Ziegler, W., and C.A. Sandberg. 1990. The Late Devonian standard conodont zonation. Courier Forschungsinstitut Senckenberg 121: $1-115$ 